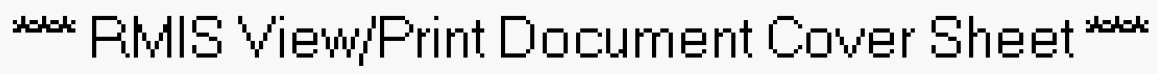

This document was retrieved from the Boeing ISEARCH System.

Accession \#: D196054745

Document \#: SD-WM-ER-441

Title/Desc:

TANK 241BY112 HEADSPACE GAS \& VAPOR CHARACTERIZATION RESULTSFOR SAMPLES COLLECTED IN $11 / 1994$ 


\begin{tabular}{|c|c|c|c|c|c|c|}
\hline \multirow{3}{*}{$\begin{array}{l}\text { 2. ECN Category } \\
\text { (mark one) } \\
\text { Supplemental } \\
\text { Direct Revision } \\
\text { Change ECN } \\
\text { Temporary } \\
\text { Standby } \\
\text { Supersedure } \\
\text { Cancel/Noid }\end{array}$} & \multirow{3}{*}{$\begin{array}{l}{[]} \\
61 \\
{[]} \\
{[]} \\
{[]} \\
{[]} \\
{[]}\end{array}$} & \multicolumn{2}{|c|}{$\begin{array}{l}\text { 3. Originator's Name, Organization, MSIN, } \\
\text { and Telephone No. } \\
\text { D. R. BRATZEL, } 75640, S 7-21 \text {, } \\
\text { 373-3579 }\end{array}$} & \multicolumn{2}{|c|}{$\begin{array}{l}\text { 3a. USQ Required? } \\
\text { [] Yes [X] No }\end{array}$} & $\begin{array}{l}\text { 4. Date } \\
09 / 27 / 95\end{array}$ \\
\hline & & \multicolumn{2}{|c|}{$\begin{array}{l}\text { 5. Project Title/No./Work order No. } \\
\text { TANK 241-BY-112 HEADSPACE GAS } \\
\text { AND VAPOR CHARACTERIZATION } \\
\text { RESULTS FOR SAMPLES COLLECTED } \\
\text { IN NOVEMBER } 1994\end{array}$} & \multicolumn{2}{|c|}{$\begin{array}{l}\text { 6. Bldg./Sys./Fac. No. } \\
2704 \mathrm{HV} / 200 \mathrm{E}\end{array}$} & $\begin{array}{l}\text { 7. Approval Designator } \\
\text { N/A }\end{array}$ \\
\hline & & \multicolumn{2}{|c|}{$\begin{array}{l}\text { 8. Document Numbers changed by this ECN } \\
\text { (includes sheet no. and rev.) } \\
\text { WHC-SD-WM-ER-441 REV } Y 0\end{array}$} & \multicolumn{2}{|c|}{$\begin{array}{l}\text { 9. Related ECN No(s). } \\
\text { N/A }\end{array}$} & 10. Related PO No. \\
\hline \multicolumn{2}{|c|}{$\begin{array}{l}\text { 11a. Modification Work } \\
\text { [] Yes (fill out Blk. } \\
11 \mathrm{~b} \text { ) } \\
\text { [X] No (NA Blks. 11b, } \\
11 \mathrm{c}, 11 \mathrm{~d} \text { ) }\end{array}$} & $\begin{array}{l}\text { 11b. Work Package } \\
\text { No. } \\
\text { N/A }\end{array}$ & \multicolumn{2}{|c|}{$\begin{array}{l}\text { I1c. Modification Work Complete } \\
\text { N/A }\end{array}$} & \multicolumn{2}{|c|}{$\begin{array}{l}\text { 11d. Restored to Original Condi- } \\
\text { tion (Temp. or Standby ECN only) } \\
\text { N/A }\end{array}$} \\
\hline
\end{tabular}

12. Description of Change

Title change and complete rewrite.

13a. Justification (mark one)

$\begin{array}{lllllll}\text { Criteria Change } & {[X]} & \text { Design Improvement } & \text { [] } & \text { Environmental } & \text { [] } & \text { Facility Deactivation } \\ \text { As-Found } & {[]} & \text { Facilitate Const } & \text { [] } & \text { Const. Error/Omission } & \text { [] } & \text { Design Error/Omission }\end{array}$

13b. Justification Details

Complete rewrite which includes all vapor sampling events to date and data qual ification. 


\begin{tabular}{|c|c|c|c|c|c|c|}
\hline \multicolumn{4}{|c|}{ ENGINEERING CHANGE NOTICE } & Page 2 of 2 & $\begin{array}{l}\text { 1. ECN } \\
625445 \\
\end{array}$ & no. from pg. 1) \\
\hline \multirow{3}{*}{$\begin{array}{l}\text { 15. Design } \\
\text { Verification } \\
\text { Required } \\
\text { [] Yes } \\
{[X] \text { No }}\end{array}$} & \multicolumn{2}{|c|}{ ENGINEERING } & \multicolumn{2}{|c|}{ CONSTRUCTION } & \multicolumn{2}{|c|}{ 17. Schedule Impact. (days) } \\
\hline & Addi tional & $\$$ & Additional & [] $\$$ & Improvement & [] \\
\hline & Savings & $\$$ & Savings & $\$$ & Delay & \\
\hline
\end{tabular}

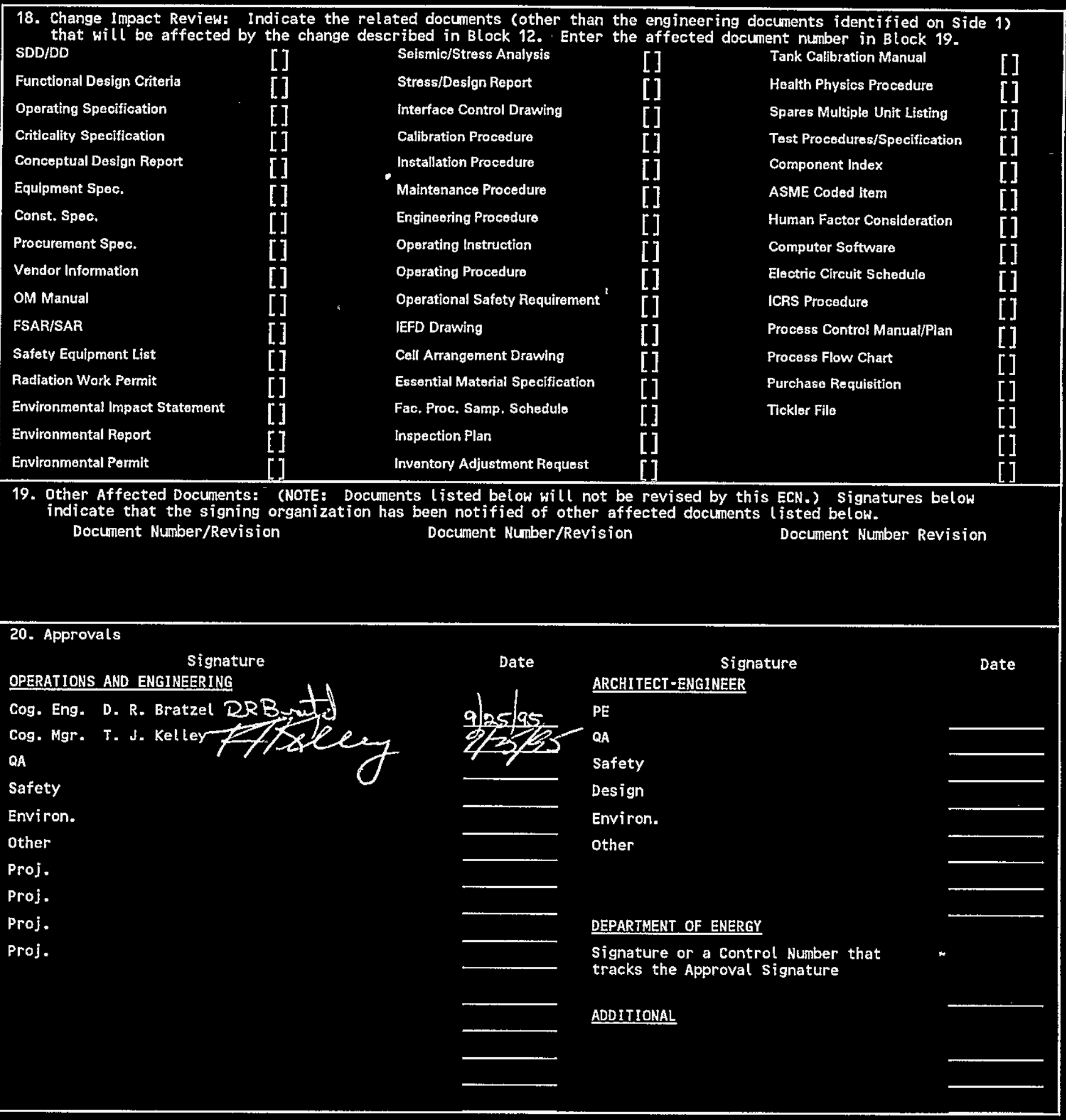




\section{RELEASE AUTHORIZATION}

\begin{tabular}{|ll|}
\hline Document Number: & WHC-SD-WM-ER-441, REV 1 \\
\hline Document Title: & $\begin{array}{l}\text { Tank 241-BY-112 Headspace Gas and Vapor } \\
\text { Characterization Results for Samples Col lected in } \\
\text { November 1994 }\end{array}$ \\
\hline Release Date: & $9 / 28 / 95$
\end{tabular}

\section{This document was reviewed following the procedures described in WHC-CM-3-4 and is: \\ APPROVED FOR PUBLIC RELEASE}

WHC Information Release Administration Specialist:
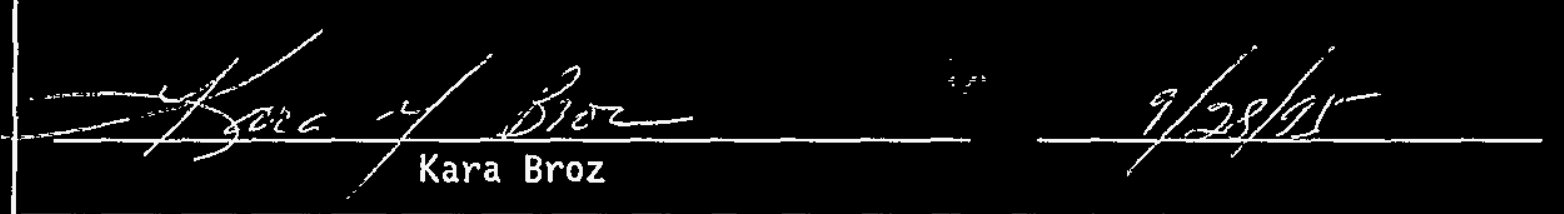

TRADEMARK DISCLATHER. Reference herein to any specific commercial product, process, or service by trade name, trademark, manufacturer, or otherwise, does not necessarily constitute or imply its endorsement, recommendation, or favoring by the United States Government or any agency thereof or its contractors or subcontractors.

This report has been reproduced from the best available copy. Available in paper copy. Printed in the United States of America. To obtain copies of this report, contact:

Westinghouse Hanford Company - Document Control Services

P.0. Box 1970, Mailstop H6-08, Richland, WA 99352

Telephone: (509) 372-2420; Fax: (509) 376-4989 


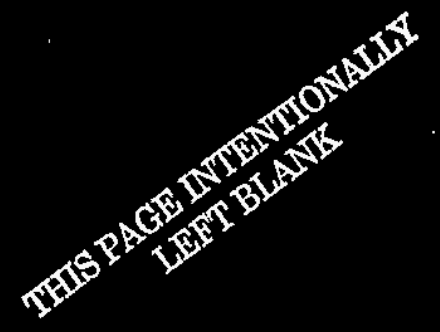




\section{Title}

TANK 241-BY-112 HEADSPACE GAS AND VAPOR CHARACTERIZATION RESULTS FOR SAMPLES COLLECTED IN NOVEMBER 1994

5. Key Words

CHARACTERIZATION OBJECTIVES, TANK HEADSPACE,

SAMPLING EVENT, INORGANIC GASES, ORGANIC VAPORS

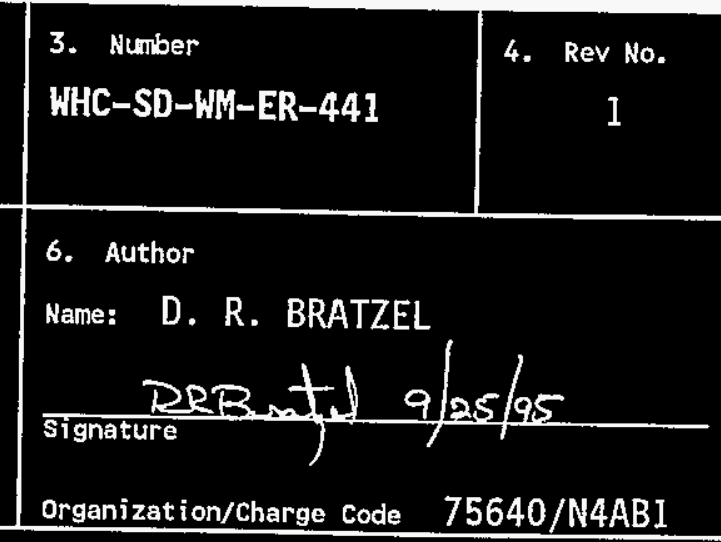

7. Abstract

Significant changes have been made to all of the original vapor characterization reports. This report documents specific headspace gas and vapor characterization results for all vapor sampling events to date. In addition, changes have been made to the original vapor reports to qualify the data based on quality assurance issues associated with the performing laboratories.

8. 


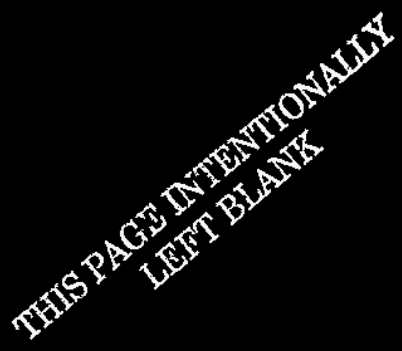




\begin{tabular}{|c|c|c|c|c|}
\hline \multicolumn{2}{|r|}{ RECORD OF REVISION } & \multicolumn{2}{|c|}{$\begin{array}{l}\text { (1) Document Number } \\
\text { WHC-SD-WM-ER-441 }\end{array}$} & Page 1 \\
\hline \multicolumn{5}{|c|}{$\begin{array}{l}\text { (2) Title } \\
\text { TANK } 241-B Y-112 \text { HEADSPACE GAS AND VAPOR CHARACTERIZATION RESULTS FOR SAMPLES COLLECTED } \\
\text { IN NOVEMBER } 1994\end{array}$} \\
\hline \multicolumn{5}{|c|}{ CHAMGE CONTROL RECORD } \\
\hline (3) Revision & (4) Description of Change - Replace, Add, and Delete Pages & \multicolumn{3}{|c|}{ Authorized for Release } \\
\hline 0 & $\begin{array}{l}\text { (7) WHC-SD-WM-ER-441, REV. 0, EDT } 612333 \\
\text { May } 31,1995\end{array}$ & (5) Log. Engr. & (6) 0 & gr. Date \\
\hline 1 RS & $\begin{array}{l}\text { Complete revision and title change. ECN } \\
625445\end{array}$ & tel & & \\
\hline & & & & \\
\hline & & & & \\
\hline & & & & \\
\hline & & & & \\
\hline & & & & \\
\hline & & & & \\
\hline & & & & \\
\hline & & & & \\
\hline & & & & \\
\hline & & & & \\
\hline & & & & \\
\hline & & & & \\
\hline
\end{tabular}




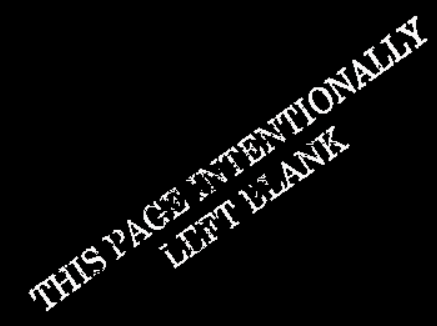




\title{
Tank 241-BY-112 Headspace Gas and Vapor Characterization Results for Samples Collected in November 1994
}

\author{
J. L. Huckaby
}

Pacific Northwest Laboratories

D. R. Bratzel

Westinghouse Fanford Company

Date Published

September 1995

Prepared for the U.S. Department of Energy

Office of Environmental Restoration and

Waste Management

(2) Westinghouse $\quad$ P.o Box 1970

Menagement and Operations Contractor for the

U.S. Department of Energy under Contract DE-ACO6.87FL10930 


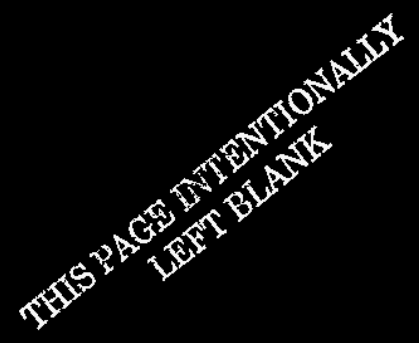


WHC-SD-WM-ER-441 REV. 1

Contents

1.0 INTRODUCTION $\ldots \ldots \ldots \ldots \ldots \ldots \ldots \ldots \ldots \ldots \ldots \ldots \ldots \ldots \ldots \ldots \ldots \ldots \ldots \ldots \ldots \ldots$

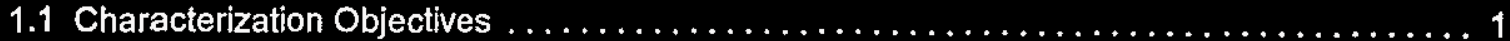

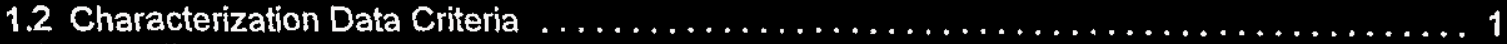

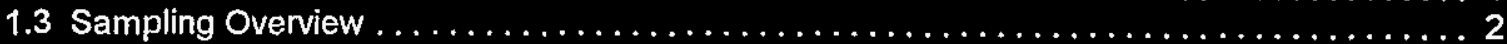

1.4 Tank Headspace Dynamics . . . . . . . . . . . . . . . . . . . . . . . . . . . 2

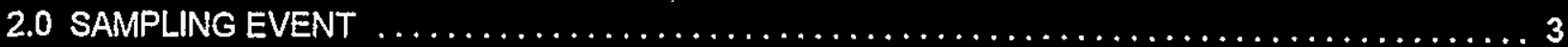

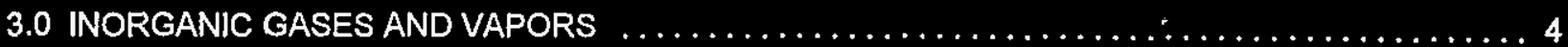

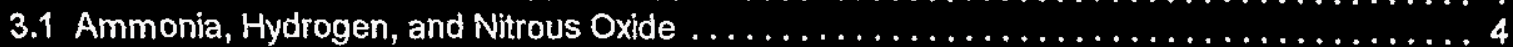

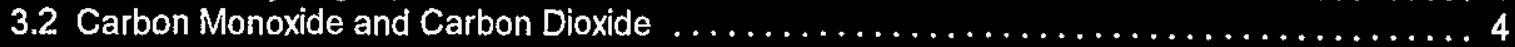

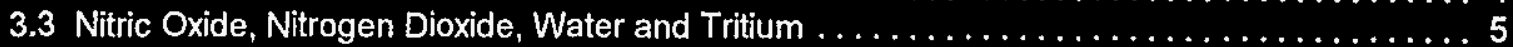

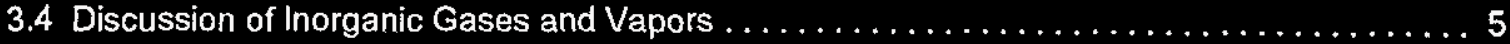

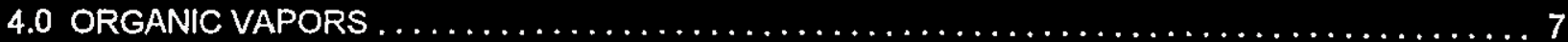

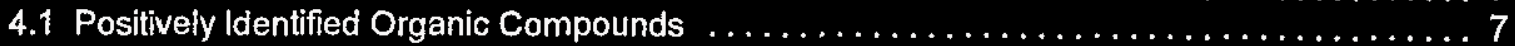

4.2 Tentatively Identified Organic Compounds $\ldots \ldots \ldots \ldots \ldots \ldots \ldots \ldots \ldots \ldots \ldots \ldots$

4.3 Discussion of Organic Compounds $\ldots \ldots \ldots \ldots \ldots \ldots \ldots \ldots \ldots \ldots \ldots \ldots \ldots$

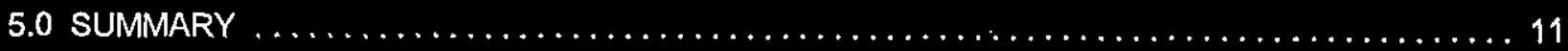

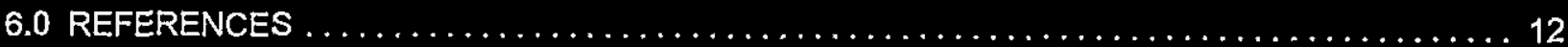

Acronyms and Abbreviations

$\begin{array}{ll}\text { CES } & \text { consensus exposure standard } \\ \text { EPA } & \text { Environmental Protection Agency } \\ \text { GC } & \text { gas chromatograph } \\ \text { GCMS } & \text { gas chromatograph/mass spectrometer } \\ \text { LFL } & \text { lower flammability limit } \\ \text { MS } & \text { mass spectrometer } \\ \text { NFPA } & \text { National Fire Protection Association } \\ \text { NPH } & \text { normal paraffinic hydrocarbon } \\ \text { ORNL } & \text { Oak Ridge National Laboratory } \\ \text { PNL } & \text { Pacific Northwest Laboratory } \\ \text { ppmv } & \text { parts per million by volume, } 1 \mathrm{ppmv}=10^{-4} \text { vol\% } \\ \text { TST } & \text { triple sorbent trap } \\ \text { vol\% } & \text { percent by volume, } 1 \text { vol\% }=10,000 \mathrm{ppmv} \\ \text { VSS } & \text { vapor sampling system } \\ \text { WHC } & \text { Westinghouse Hanford Company }\end{array}$

\section{Acknowledgements}

The author wishes to thank Chris Simonen for her work verifying data and generating tables, and Shas Mattigod for his help with the construction and reviews of this document. 


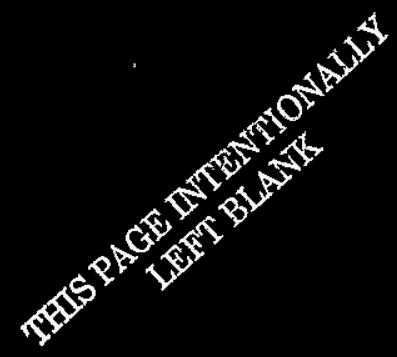


WHC-SD-WM-ER-441 REV. 1

Tank 241-BY-112 Headspace Gas and Vapor Characterization Results

for Samples Collected in November 1994

\subsection{INTRODUCTION}

\subsection{Characterization Objectives}

Tank BY-112 headspace gas and vapor samples were collected and analyzed to help determine the potential risks of fugitive emissions to tank farm workers. The drivers and objectives of waste tank headspace sampling and analysis are discussed in Program Plan for the Resolution of Tank Vapor /ssues (Osborne and Huckaby 1994). Tank BY-112 was vapor sampled in accordance with Data Quality Objectives for Generic In-Tank Health and Safety Issue Resolution (Osborne et al. 1994). Results presented here represent the best available data on the headspace constituents of tank BY-112.

\subsection{Characterization Data Criteria}

Data Quality Objectives for Generic In-Tank Health and Safety Issue Resolution describes parameters for data collection to ensure appropriate conclusions can be drawn from the data. Tank headspace characterization data were collected to help in the evaluation of 1) headspace flammability, and 2) identification and quantification of compounds of toxicological concern.

Single Shell Tank Interim Operational Safety Requirements (Dougherty 1995) specifies that combustible constituents in tank headspaces be maintained below $25 \%$ of the lower flammability limit (LFL). This essentially agrees with National Fire Protection Association requirements that combustible concentrations be maintained at or below $25 \%$ of the LFL (NFPA 1992). Current governing operating specifications for Watchlist tanks, such as tank BY-112, specify that combustible constituents be maintained at or below $20 \%$ of the LFL (WHC 1995a).

Headspace characterization data are used by Westinghouse Hanford Company (WHC) Tank Waste Remediation Systems Industrial Hygiene as source term data in the industrial hygiene strategy to protect workers from tank fugitive emissions. Because selection of worker protective equipment must be based on industrial hygiene monitoring of the work place and not on source term data (29 CFR 1910.120), tank headspace characterization data can not be used for this purpose. Furthermore, because there are mechanisms by which headspace constituents can be either diluted or concentrated as they are released to the atmosphere, the headspace characterization data should not be considered to be representative of emissions at the point of emission.

These statements notwithstanding, the data quality objectives document specifies that the industrial hygiene group be advised if constituents with toxicological properties exceed $50 \%$ of the appropriate consensus exposure standard (CES) for non-carcinogens, or $10 \%$ of the appropriate CES for carcinogens. A CES is defined as the most stringent of known regulatory or recommended toxicological values for the workplace (Osborne et al. 1994). 


\subsection{Sampling Overview}

Tank headspace characterization data presented here are from a single sampling event. Samples collected are thought to have been representative of the tank BY-112 headspace when the tank was sampled, and sample analyses were designed to provide a reasonably accurate and complete characterization of the significant headspace constituents (Meacham et al. 1995). No assessment has been made of how the tank BY-112 headspace composition changes with time, though studies of tank C103 suggest that composition changes probably occur very sjowly in the passively ventilated tanks (Huckaby and Story 1994).

\subsection{Tank Headspace Dynamics}

Tank BY-112 is the third tank in a 3-tank cascade with tanks BY-110 and BY-111. It is connected to tank BY-111 via a 7.4-cm (2.9-in.) inside diameter, 7.6-m (25-ft) long cascade line. Tanks BY-110 and BY-111 are also connected by a similar line. Since these cascade lines connect the headspaces of these tanks, gases and vapors originating from the wastes in tank BY-110 or BY-111 may be transferred to tank BY-112 (unless the cascade lines are obstructed).

The cascade of tanks $B Y-110, B Y-111$, and $B Y-112$ is passively ventilated, which means that the tanks are allowed to exhale air, waste gases, and vapors as the barometric pressure falls, and inhale ambient air as the barometric pressure rises. Each of these tanks has its own filtered breather riser. Barometric pressure typically rises and falls on a diurnal cycle, producing an average daily exchange of air equal to about $0.46 \%$ of each tank headspace (Huckaby 1994). Changes in the concentrations of tank headspace constituents due to barometric pressure changes are consequently very slow. 


\subsection{SAMPLING EVENT}

Headspace gas and vapor samples were collected from tank BY-112 using the vapor sampling system (VSS) on November 18, 1994 by WHC Sampling and Mobile Laboratories (WHC 1995b). Sample collection and analysis were performed as directed by Tank 241-BY-112 Tank Characterization Plan (Homi 1994). The tank headspace temperature was determined to be $23.3^{\circ} \mathrm{C}$. Air from the BY-112 headspace was withdrawn from a single elevation via a $7.9-\mathrm{m}$ long heated sampling probe mounted in riser 21 , and transferred via heated tubing to the VSS sampling manifold. All heated zones of the VSS were maintained at approximately $50^{\circ} \mathrm{C}$. All tank air samples were collected between 11:06 a.m. and 2:26 p.m., with no anomalies noted.

Sampling media were prepared and analyzed by WHC, Oak Ridge National Laboratories (ORNL), and Pacific Northwest Laboratories (PNL). The 40 tank air samples and 2 ambient air control samples collected are listed in Table 2-1 by analytical laboratory. Table 2-1 also lists the 14 trip blanks and 2 field blanks provided by the laboratories.

A general description of vapor sampling and sample analysis methods is given by Huckaby et al. (1995). The sampling equipment, sample collection sequence, sorbent trap sample air flow rates and flow times, chain of custody information, and a discussion of the sampling event itself are given in WHC (1995b). 
WHC-SD-WM-ER-441 REV. 1

\subsection{INORGANIC GASES AND VAPORS}

Analytical results of sorbent trap and SUMMA ${ }^{T M, 1}$ canister tank air samples for selected inorganic gases and vapors are given in Tabie 3-1 in parts per million by volume (ppmv) in dry air. The concentration of water vapor given in Table 3-1 has been adjusted to tank conditions as given in Section 3.3. Inorganic analyte sorbent traps and SUMMATM canisters were prepared and analyzed by PNL, at PNL quality assurance impact level 2 (Clauss et al. 1995).

Analyses of the inorganic vapor sorbent traps were performed within 32 days of sample collection, and analyses of SUMMA ${ }^{T M}$ canisters for inorganic compounds were performed 88 days after sample collection (Ligotke 1995). Thus the administratively chosen 60-day holding time requirement of the WHC quality assurance project plan (Keller 1994) was satisfied only for analyses of the sorbent traps . It should be noted that the inorganic compounds analyzed for in SUMMA ${ }^{\text {TM }}$ canisters would be expected to be very stable in the SUMMA ${ }^{\mathrm{TM}}$ canisters, and the results may not have been affected even though the 60-day holding time requirement was exceeded.

\subsection{Ammonia, Hydrogen, and Nitrous Oxide}

Ammonia concentration in the headspace of tank BY-112 was measured at $63 \mathrm{ppmv}$. Ammonia has been observed in virtuaily all of the passively ventilated waste tanks sampled to date, at concentrations ranging from about 3 ppmv in tank C-108 (Lucke et al. 1995), to 1040 ppmv in BY-108 (McVeety et al. 1995). Given the LFL of ammonia in air is about $15 \%$ by volume (vol\%), the measured 63 ppmv corresponds to less than $0.05 \%$ of the LFL, and does not contribute appreciably to the flammability of the headspace.

The concentration of hydrogen in tank BY-112 was determined to be $<94 \mathrm{ppmv}$. Hydrogen in the waste tanks is of concern as a fuel. Given that the LFL for hydrogen in air is about $4 \mathrm{vol} \%, 94 \mathrm{ppmv}$ hydrogen concentration in tank BY-112 would correspond to about $0.24 \%$ of its LFL. At this level, hydrogen is not a flammability concern in tank BY-112.

The nitrous oxide concentration in tank BY-112 was measured at 40 ppmv. Nitrous oxide has been detected in other passively ventilated waste tanks at concentrations as low as about 12 ppmv in tank TX105 (Klinger et al. 1995), and as high as about 868 ppmv in tank U-103 (Ligotke et al. 1995). Under proper conditions, nitrous oxide can serve as an oxidizer to support combustion. However, Cashdoliar et al. (1992) found that nitrous oxide had no significant effect on the flammability of hydrogen and air mixtures for hydrogen concentrations less than $20 \mathrm{vol} \%$, and that "small amounts of nitrous oxide (relative to air) do not appear to have much effect on the flammability". Their results suggest the measured nitrous oxide concentration is much too low to have a significant effect on the flammability of the tank BY-112 headspace.

\subsection{Carbon Monoxide and Carbon Dioxide}

Carbon monoxide in the tank BY-112 headspace was characterized as $<12$ ppmv. In ambient air it typically ranges from 0.05 to $0.15 \mathrm{ppmv}$. Because different analytical methods have been used to measure carbon monoxide in the waste tanks sampled to date, the information on carbon monoxide has varied from tank to tank. However, elevated waste tank headspace carbon monoxide concentrations are common, and are thought to be due to the decomposition of organic waste in the tanks. Carbon monoxide has not been

1 SUMMA is a trademark of Molectrics, Inc., Cleveland, Ohio. 
WHC-SD-WM-ER-441 REV. 1

measured at very high levels in any of the waste tanks, the highest level measured to date was [26.7 ppmv] in tank C-1032 (Huckaby and Story 1994).

The average carbon dioxide concentration in the tank BY-112 headspace, $121 \mathrm{ppmv}$, is significantly lower than it is in ambient air. Carbon dioxide is normally present in the ambient air at a concentration of 350 to $400 \mathrm{ppmv}$, and is typically lower than ambient in the waste tank headspaces. Carbon dioxide introduced by air exchange with the atmosphere is readily absorbed by caustic supernatant and interstitial liquids of the waste tanks, and converted to carbonate in solution. The $121 \mathrm{ppmv}$ of carbon dioxide measured in tank BY-112 is about average for the waste tanks sampled to date.

\subsection{Nitric Oxide, Nitrogen Dioxide, Water and Tritium}

Nitric oxide and nitrogen dioxide concentrations in the tank BY-112 headspace were determined to be 0.18 ppmv and $\leq 0.02$ ppmv, respectively. These are both acid gases that would have very low equilibrium concentrations above the high pH sludge in tank BY-112. The measurable presence of nitric oxide may be due to its formation from oxygen and nitrogen in the radiation field of the headspace. These constituents could potentially serve as oxidizers to support combustion, but at the measured concentrations would have a negligible effect on the flammability of the tank BY-112 headspace.

The water vapor concentration of tank BY-112 was determined to be about $11.2 \mathrm{mg} / \mathrm{L}$, at the measured tank headspace temperature of $23.3^{\circ} \mathrm{C}$ and pressure of $1001 \mathrm{mbar}$ (751 torr), (WHC 1995b). This corresponds to a water vapor partial pressure of $15.3 \mathrm{mbar}(11.5 \mathrm{torr})$, to a dew point of $13.3^{\circ} \mathrm{C}$, and to a relative humidity of $53 \%$.

Silica gel sorbent traps were used to test for tritium. It is assumed that tritium produced by the waste combines with hydroxide ions to form tritium-substituted water. Evaporation of the tritium-substituted water would then result in airborne radioactive contamination. Silica gel sorbent traps adsorb virtually all (normal and tritium-substituted) water vapor from the sampled tank air, and are analyzed at the WHC 222-S laboratory. Radiochemical analysis of the silica gel trap indicated the total activity of the headspace to be less than $50 \mathrm{pCi} / \mathrm{L}$ (WHC 1995b).

\subsection{Discussion of Inorganic Gases and Vapors}

Aside from water and carbon dioxide, the most abundant waste constituents in the tank BY-112 headspace are ammonia and nitrous oxide. These have been detected in most tank headspaces sampled to date, and along with hydrogen, are usually the dominate waste species.

The relative standard deviations of the inorganic gas and vapor results given in the last column in Table 3-1 are very good. Relative standard deviations range from $8.6 \%$ for carbon dioxide to $15 \%$ for nitrous oxide results. Because the precision reported depends both on sampling parameters (e.g., sample flow rate and flow time for sorbent traps) and analytical parameters (e.g., sample preparation, dilutions, etc.), the small relative standard deviations suggest proper control was maintained both in the field and in the laboratories.

As discussed briefly in Section 1.4, it is possible that gases and vapors generated by the waste in tanks BY110 and $B Y-111$ could be transferred to tank BY-112 via the cascade lines. If significant exchange of selected inorganic gases and vapors were taking place between adjacent tanks, either their headspace

\footnotetext{
2 The carbon monoxide measurement in tank C-103 was made by Oregon Graduate Institute of Science and Technology, and placed in brackets to emphasize it should be considered secondary data.
} 
compositions would be very similar, or all constituents detected in one tank would be at or equal or higher concentrations in the other tank. The data in Table 3-2 are consistent with the premise that air, gases, and vapors could be transferring from tank BY-111 to tank BY-112 (waste species are at higher concentrations in tank BY-112 than in BY-111, and carbon dioxide is lower), but do not constitute proof that this is occurring. 


\subsection{ORGANIC VAPORS}

Organic vapors in the tank BY-112 headspace were sampled using SUMMA ${ }^{\mathrm{TM}}$ canisters, which were analyzed by PNL, and triple sorbent traps (TSTs), which were analyzed by ORNL. Gas chromatographs (GCs) equipped with mass spectrometer (MS) detectors were used by PNL and ORNL to separate, identify, and quantitate the analytes. Descriptions of sample device cleaning, sample preparations, and analyses are given by Jenkins et al. (1995a) and Clauss et al. (1995).

SUMMA ${ }^{\text {TM }}$ sample results should be considered to be the primary organic vapor data for tank BY-112. These results were produced at PNL quality assurance impact level 2 . However, PNL analyses were not completed until 81 days after sample collection, which was beyond the administratively chosen 60-day holding time of the WHC quality assurance project plan (Keller 1994). No holding time study has been done to determine the stability of organic analytes in SUMMA ${ }^{\mathrm{TM}}$ canisters in the chemical matrix of tank samples.

ORNL analyses of TST samples from this and other waste tanks generally agree with, support, and augment the SUMMA ${ }^{T M}$ sample results. However, because certain WHC quality assurance requirements were not satisfied by ORNL, the quality assurance assessment of ORNL. by Hendrickson (1995) should be reviewed before results unique to the TST samples are used for decision making.

All TSTs prepared by ORNL had 3 surrogate compounds added to evaluate sample matrix effects, potential handling, storage, and shipment problems, and analytical instrumentation performance (Jenkins et al. 1995a). ORNL evaluated the surrogate recoveries using a statistical approach similar to that prescribed by SW 846 Method 8260 A Volatile Organic Compounds by Gas ChromatographyMass Spectrometry (GCMS) Capillary Column Technique (EPA 1992). Using this approach, ORNL reported that all surrogates had standard deviation values within the $95 \%$ confidence interval for variance, indicating that no bias was introduced in the measurement of analyte quantities (Jenkins 1995a).

\subsection{Positively Identified Organic.Compounds}

Positive identification of organic analytes using the methods employed by PNL and ORNL involves matching the $\mathrm{GC}$ retention times and MS data from a sample with that obtained when known compounds were analyzed. The concentration of an analyte in the sample is said to be quantitatively measured if the response of the GCMS has been established at several known concentrations of that analyte (i.e., the GCMS has been calibrated for that analyte), and the MS response to the analyte in the sample is between the lowest and highest responses to the known concentrations (i.e., the analyte is within the calibration range).

ORNL and PNL were assigned different lists of organic compounds, or target analytes, to positively identify and measure quantitatively. The ORNL target analyte list was derived from a review of the tank $\mathrm{C}-103$ headspace constituents by a panel of toxicology experts (Mahlum et al. 1994). The PNL target analyte list included the 40 compounds in the Environmental Protection Agency (EPA) task order 14 (TO-14) method, which are primarily halocarbons and common industrial solvents (EPA 1988), plus 14 analytes selected mainly from the toxicology panel's review of tank C-103.

Table 4- 1 lists the 4 organic compounds positively identified and quantitated in SUMMA ${ }^{\text {TM }}$ samples. SUMMA ${ }^{\text {TM }}$ organic analyses were performed according to the TO- 14 methodology, except for methane analysis, which was analyzed with the inorganic gases (Clauss et al. 1995). Only 2 of the 40 TO-14 target analytes and only 2 of the 14 additional target analytes were measured to be above the $0.005 \mathrm{ppmv}$ detection limit of the analyses. Averages reported are from analyses of 3 SUMMA $^{\text {TM }}$ canister samples. 


\section{WHC-SD-WM-ER-441 REV. 1}

Jenkins et al. (1995a) report the positive identification of 24 of 27 target analytes in TST samples. 1,1Dichloroethene, dibutyl butylphosphonate, and tributyl phosphate were the only TST target analytes not detected in the TST samples. The average concentrations of 3 quantitated target analytes, from the analysis of 3 TSTs, are given in Table 4-2. Table 4-3 lists 16 compounds which were determined to be outside of the instrument calibration range in at least 1 of the TST samples, and consequently not quantitated. The 5 other positively identified compounds are listed in Table 4-4 because analyses were performed after their ORNL analyte-specific practical holding times had been exceeded. Data in Tables 43 and $4-4$ may not be accurate to within $\pm 30 \%$ as specified by Burnum (1995).

Based on a practical holding time study performed by ORNL the reported concentrations of propanone, butanal, 1-butanol, 2-pentanone, and n-pentanenitrile may have been affected by the 62 day period between sample collection and analysis (Jenkins 1995b). The concentration of these five analytes are reported in Table 4-4. The practical holding time is defined as the holding time for which there is a $15 \%$ risk that the concentration of an analyte in the sample will be below its initial concentration. Jenkins et al. (1995b) describe the ORNL practical holding time study, and report practical holding times for these compounds.

Eleven target analytes were common to both TST and SUMMA ${ }^{\mathrm{TM}}$ analyses. Table 4-5 lists these, and their reported average concentrations in TST and SUMMA ${ }^{T M}$ samples. The data given in Table 4-5 indicate these methods agree that 8 of the 11 listed analytes are at or below about 0.006 ppmv. Propanone, ethanenitrile, and toluene are each reported to be at higher concentrations in TST samples than in SUMMA ${ }^{\text {TM }}$ samples.

The most abundant analytes in Tables 4-1 through 4-4 are propanone, trichlorofluoromethane, 2-butanone, and ethanenitrile, each of which was measured to be at or above $0.1 \mathrm{ppmv}$. At the reported concentrations, the target analytes do not individually or collectively represent a flammability hazard.

\subsection{Tentatively Identified Organic Compounds}

In addition to the target analytes, the ORNL and PNL analytical procedures allow the tentative identification of other organic compounds. Tentative identification of anaiytes was performed by comparing the MS molecular fragmentation patterns with a library of known MS fragmentation patterns. This method allows an organic analyte to be identified (with reasonable certainty) as an alkane, a ketone, an aldehyde, etc., and may also determine its molecular weight. The method usually does not, however, allow the unambiguous identification of structural isomers, and this ambiguity increases with analyte molecular weight. Using this method, many analytes can be tentatively identified with reasonable confidence without having to inject each into the GC/MS to determine their GC retention times or specific MS patterns.

By the nature of the sampling devices, virtually all organic vapors present in the tank headspace are collected by both TST and SUMMA ${ }^{\mathrm{TM}}$ samples. Analyses of the samples are designed to recover, separate, and identify the organic vapors in the samples. TSTs are not good for collecting highly volatile compounds (i.e., molecules more volatile than propane), but are quite good for most others. In contrast, the recovery of very low volatility compounds (e.g., molecules with more than about 15 carbon atoms) and some polar compounds with moderate volatility (e.g., butanal) from SUMMA ${ }^{\mathrm{TM}}$ samples has been problematic.

The list of tentatively identified compounds recovered from SUMMA ${ }^{T M}$ samples, with estimated concentrations, is given in Table 4-6. Compounds are listed in Table 4-6 in the order by which they eluted chromatographically, and only non-zero results are included in the reported averages. The list of tentatively identified compounds detected in TST samples, and their estimated concentrations, is given in Table 4-7. Compounds are listed in Table 4-7 according to the order by which the eluted chromatographicaily. The 


\section{WHC-SD-WM-ER-441 REV. 1}

averages reported by ORNL in Table 4-7 are all 3-sample averages, and if an analyte was not detected in a sample, its concentration in that sample was considered to be zero for averaging purposes. Estimated concentrations are in $\mathrm{mg} / \mathrm{m}^{3}$, based on dry air at $0^{\circ} \mathrm{C}$ and 1.01 bar.

Because the list of tentatively identified organic compounds in TST samples is long and locating any given compound may be difficult, the list has been sorted alphanumerically by compound name in Table 4-8, and also in order of decreasing estimated concentrations in Table 4-9. Numbers in the first columns of Tables 4-8 and 4-9 (Cmpd \#) identify the elution order of the compound in Table 4-7.

The ORNL and PNL methods used to tentatively identify and estimate concentrations are described by Jenkins et al. (1995a) and Clauss et al. (1995), respectively, and should be reviewed before this data are used for decision making. Concentrations given in Tables 4-6 through 4-9 should be considered rough estimates. Results in Tables 4-6 through 4-9 are presented in terms of observed peaks, and are not adjusted for the occurrence of split chromatographic peaks (e.g., Cmpd \# 6 and 7 in Table 4-7) or the assignment of the same identity to different peaks (e.g., Cmpd \#53 and 58 in Table 4-7). In these instances, the estimated concentration of a compound appearing in different peaks is simply the sum of the individual peak estimates.

\subsection{Discussion of Organic Compounds}

A convenient way to consider the organic compounds listed in Tables 4-1 through 4-7 is to separate them into 2 categories: 1) Organic compounds added to tank BY-112 as waste that are still evaporating; and 2) organic compounds that have been generated by reactions of the original waste.

The first category encompasses all organic compounds that were placed into the tank as waste. It includes the tentatively identified alkyl-substituted decahydronaphthalenes, and semivolatile branched and straightchain alkanes, which were used as diluents of tributyl phosphate in various plutonium extraction processes. The semivolatile straight-chain alkanes (i.e., $n$-undecane, $n$-dodecane, $n$-tridecane, $n$-tetradecane, and $n$ pentadecane) are often referred to in Hanford site literature as the normal parafinic hydrocarbons (NPHs).

Trace amounts of a tentatively identified cyclosiloxane (i.e., Cmpd \# 23 in Table 4-7) may also be in the category of waste additions. Small quantities of siloxanes may have been introduced to the waste tank through their use as process surfactants, but they may also be present in the headspace due to their use in liquid traps at the tank's breather riser.

The second category includes all organic compounds that have been generated via radioiytic and chemical reactions of the waste. The majority of compounds listed in Tables 4-1 through 4-9 fall into this category, including the alcohols, aldehydes, ketones, nitriles, alkenes, alkyl nitrates, and volatile alkanes, all of which have been associated with the degradation of the NPHs. While both larger and smaller molecules are generated from the waste, the most abundant of these in the headspace are the smaller, short-chain volatile compounds.

Small amounts of the tributyl phosphate diluents and their degradation products is reason to expect trace amounts of tributyl phosphate to be present in the tank waste. The low volatility of tributyl phosphate, and its tendency to adsorb on glass fiber filters during sampling, apparently preclude its measurement in the tank BY-112 samples. 1-Butanol, known to be a product of the hydrolysis of tributyl phosphate, is at a relatively low concentration in the tank BY-112 samples. In TST samples, 1-butanol and other alcohols are at similar concentrations; the average methanol, ethanol, 2-propanol, and 1-butanol concentrations in TSTs samples are $0.36,0.083,0.13$, and $0.20 \mathrm{mg} / \mathrm{m}^{3}$, respectively. Based on these considerations, it is likely that the amounts of tributyl phosphate in the tank BY-112 waste and headspace are very low. 


\section{WHC-SD-WM-ER-441 REV. 1}

The total organic vapor concentration of tank BY-112 was estimated by Jenkins et al. (1995a) to be about $5.8 \mathrm{mg} / \mathrm{m}^{3}$. This is the summation of concentrations of positively and tentatively identified compounds in 3 TST samples by GCMS.

Tank BY-112 is known to have contained liquid tributyi phosphate "diluted with degraded kerosene" (Schulz 1968). Schulz's assessment of the organic liquid was in preparation for application of the In Tank

Solidification (ITS) process to tank BY-112, and he states that "All, or, at least most, of the organic solution will likely steam distill during ITS operations in the 112 BY tank." The vapor samples collected in November 1994, seem to support Schulz' prediction. The total organic vapor concentration has been estimated to be relatively low, even compared to the other tanks to which it is connected (Table 3-2). Furthermore, the principle signature of tributyl phosphate in the headspace, 1-butanol, is also present at a relatively low concentration.

In summary, the tank BY-112 headspace has a moderate to low level of organic vapors. While having many of the same organic vapors as NPH-rich tanks, the alcohols are more prominent and the aldehydes less prevalent in tank BY-112. The organic liquid present in tank BY-112 before operation of the ITS process, while leaving its signature, apparently does not still exist. 


\subsection{SUMMARY}

The tank BY-112 headspace was sampled in November 1994 for gases and vapors to address flammability and industrial hygiene concerns. Collection and analysis of samples has been reported. It was determined that no headspace constituents exceeded the flammability or industrial hygiene notification limits specified in the current Vapor Sampling and Analysis Plan (Homi 1995). 



\subsection{REFERENCES}

29 CFR 1910.120, 1993, "Hazardous Waste Operations and Emergency Response", Code of Federal Regulations.

Burnum, S. T., 1995, Qualification of Reported WHC Vapor Program Data, (letter 95-CHD-065 to president, Westinghouse Hanford Company, August 18), Department of Energy, Richland Operations Office, Richland, Washington.

Cashdollar, K. L..,M. Hertzberg, I. A. Zlochower, C. E. Lucci, G. M. Green, and R. A. Thomas, 1992, Laboratory Flammability Studies of Mixtures of Hydrogen, Nitrous Oxide, and Air, WHC-SD-WMES-219 Rev. 0, Westinghouse Hanford Company, Richland, Washington.

Clauss, T. W., M. W. Ligotke, K. H. Pool, R. B. Lucke, B. D. McVeety, G. S. Klinger, K. B. Olsen, M. McCulloch, J. S. Fruchter, and S. C. Goheen, 1995, Vapor Space Characterization of Waste Tank 241-BY-112: Results from Samples Collected Through the Vapor Sampling System on 11/18/94, PNL-10598 UC-606, Pacific Northwest Laboratory, Richland, Washington.

Dougherty, L. F., 1995, Single Shell Tank Interim Operational Safety Requirements, WHC-SD-WM-OSR005 Rev. 0, Westinghouse Hanford Company, Richland, Washington.

EPA 1988, Compendium of Methods for the Determination of Toxic Organic Compounds in Ambient Air, PB90-127374, U.S. Environmental Protection Agency, Washington, D.C.

EPA 1992, Test Methods for Evaluating Solid Waste, SW-846 Rev. 1, U.S. Environmental Protection Agency, Washington, D.C.

Hendrickson, R. W., 1995, Tank Vapor Characterization Oak Ridge National Laboratories Quality Assurance Assessment, TWRSQA-95-0012, Westinghouse Hanford Company, Richland, Washington.

Homi, C. S., 1994, Tank 241-BY-112 Tank Characterization Plan, WHC-SD-WM-TP-281 Rev. 0, Westinghouse Hanford Company, Richland, Washington.

Homi, C. S., 1995, Vapor Sampling and Analysis Plan, WHC-SD-WM-TP-335 Rev. OG, Westinghouse Hanford Company, Richland, Washington.

Huckaby, J. L., 1994, Tank 241-C-103 Headspace Flammability, WHC-EP-0734 Rev. 1, Westinghouse Hanford Company, Richland, Washington.

Huckaby, J. L., H. Babad, and D. R. Bratzel, 1995, Headspace Gas and Vapor Characterization Summary for the 43 Vapor Program Suspect Tanks, WHC-SD-WM-ER-514, Rev. 0, Westinghouse Hanford Company, Richland, Washington.

Huckaby, J. L., and D. R. Bratzel, 1995a, Tank 241-BY-110 Headspace Gas and Vapor Characterization Results for Samples Collected in November 1994, WHC-SD-WM-ER-429 Rev. 2, Westinghouse Hanford Company, Richland, Washington.

Huckaby, J. L., and D. R. Bratzel, 1995b, Tank 241-BY-111 Headspace Gas and Vapor Characterization Results for Samples Collected in May 1994 November 1994, WHC-SD-WM-ER-440 Rev. 1, Westinghouse Hanford Company, Richland, Washington. 


\section{WHC-SD-WM-ER-441 REV. 1}

Huckaby, J. L., and M. S. Story, 1994, Vapor Characterization of Tank 241-C-103, WHC-EP-0780 Rev. 0, Westinghouse Hanford Company, Richland, Washington.

Jenkins, R. A., 1995a, Untitled, (Letter 090195A to D. Bratzel, September 1), Oak Ridge National Laboratory, Oak Ridge, Tennessee.

Jenkins, R. A., 1995b, Untitled, (Letter 091495A to D. Bratzel, September 14), Oak Ridge National Laboratory, Oak Ridge, Tennessee.

Jenkins, R. A, A. B. Dindal, C. E. Higgins, C. Y. Ma, M. A. Palausky, J. T. Skeen, and C. K. Bayne, 1995a, Analysis of Tank 241-BY-112 Headspace Components, ORNL-CASD-FR-241BY112.95 Rev. 0, Oak Ridge National Laboratory, Oak Ridge, Tennessee.

Jenkins, R. A, A. B. Dindal, C. Y. Ma, M. A. Palausky, J. T. Skeen, and C. K. Bayne, 1995b, Analysis of Tank 241-TY-104 Headspace Components, ORNL-CASD-FR-241TY104.95 Rev. 1, Oak Ridge National Laboratory, Oak Ridge, Tennessee.

Keller, K.K., 1994, Quality Assurance Project Plan for Tank Vapor Characterization, WHC-SD-WM-QAPP. 013 Rev.2, Westinghouse Hanford Company, Richland, Washington.

Klinger, G. S., T. W. Clauss, M. W. Ligotke, K. H. Pool, R. B. Lucke, B. D. McVeety, O. P. Bredt, J. S. Young, M. McCulloch, J. S. Fruchter, and S. C. Goheen, 1995, Vapor Space Characterization of Waste Tank 241-7X-105: Results from Samples Collected Through the Vapor Sampling System on 12/20/94, PNL-10594 UC-606, Pacific Northwest Laboratory, Richland, Washington.

Ligotke, M. W. 1995, PNL Vapor Project Analytical Holding Times, (Letter to D.R. Bratzel, September 23, 1995), Pacific Northwest Laboratory, Richland, Washington.

Lucke, R. B., M. W. Ligotke, K. H. Pool, T. W. Clauss, A. K. Sharma, B. D. McVeety, M. McCulloch, J. S. Fruchter, and S. C. Goheen, 1995, Vapor Space Characterization of Waste Tank 241-C-108: Results from Samples Collected Through the Vapor Sampling System on 8/5/94, PNL-10351' UC606, Pacific Northwest Laboratory, Richland, Washington.

Mahlum, D. D., J. Y. Young, and R. E. Weller, 1994, Toxicologic Evaluation of Analytes from Tank 231-C103, PNL-10189, Pacific Northwest Laboratory, Richland, Washington.

McVeety, B. D., T. W. Clauss, M. W. Ligotke, K. H. Pool, R. B. Lucke, G. S. Klinger, J. S. Young, M. McCulloch, J. S. Fruchter, and S. C. Goheen, 1995, Vapor Space Characterization of Waste Tank 241-BY-108: Results from Samples Collected on 10/27/94, PNL-10495 UC-606, Pacific Northwest Laboratory, Richland, Washington.

Meachem, J.E., H. Babad, R.J. Cash, G.T. Dukelow, S.J. Eberlien, D.W. Hamilton, G.D. Johnson, J.W. Osborne, M.A. Payne, D.J. Sherwood, D.A. Turner, and J.L. Huckaby, 1995, Approach for Tank Safety Characterization of Hanford Site Waste, WHC-EP-0843 Rev,0, UC-2070, Westinghouse Hanford Company, Richland, Washington.

NFPA 1992, Standard on Explosion Prevention Systems, NFPA 69, National Fire Protection Association, Quincy, Massachusetts.

Osborne, J. W., and J. L. Huckaby, 1994, Program Plan for the Resolution of Tank Vapor Issues, WHC-EP0562 Rev. 1, Westinghouse Hanford Company, Richland, Washington. 


\section{WHC-SD-WM-ER-441 REV. 1}

Osborne, J. W., J. L. Huckaby, T. P. Rudolph, E. R. Hewitt, D. D. Mahlum, J. Y. Young, C. M. Anderson, 1994, Data Quality Objectives for Generic $I n-T a n k$ Health and Safety issue Resolution, WHC-SDWM-DQO-002, Westinghouse Hanford Company, Richland, Washington.

Schulz, W. W., 1968, Characterization of the Organic Material in the 112 BY Tank, BNWL-CC-1517, Pacific Northwest Laboratory, Richland, Washington.

WHC 1995a, Operating Specinications for Watchlist Tanks, OSD-T-151-00030, Rev. B-9, Westinghouse Hanford Company, Richland, Washington.

WHC 1995b, Vapor and Gas Sampling of Single-Shell Tank 241-C-107 Using the Vapor Sampling System, WHC-SD-WM-RPT-129, Westinghouse Hanford Company, Richland, Washington. 


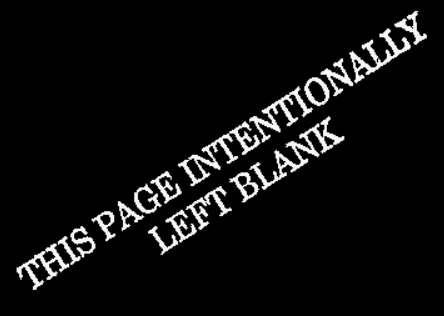




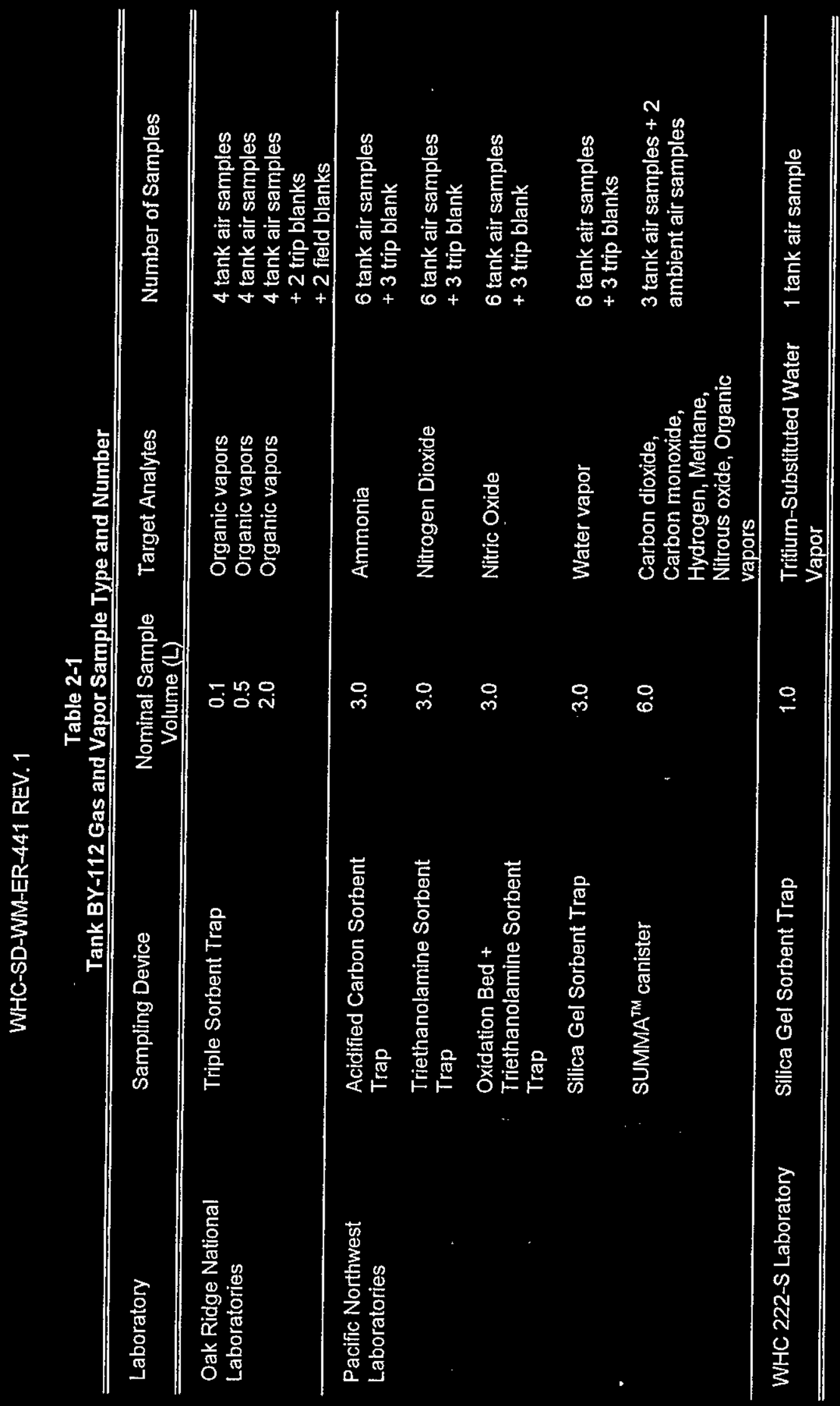




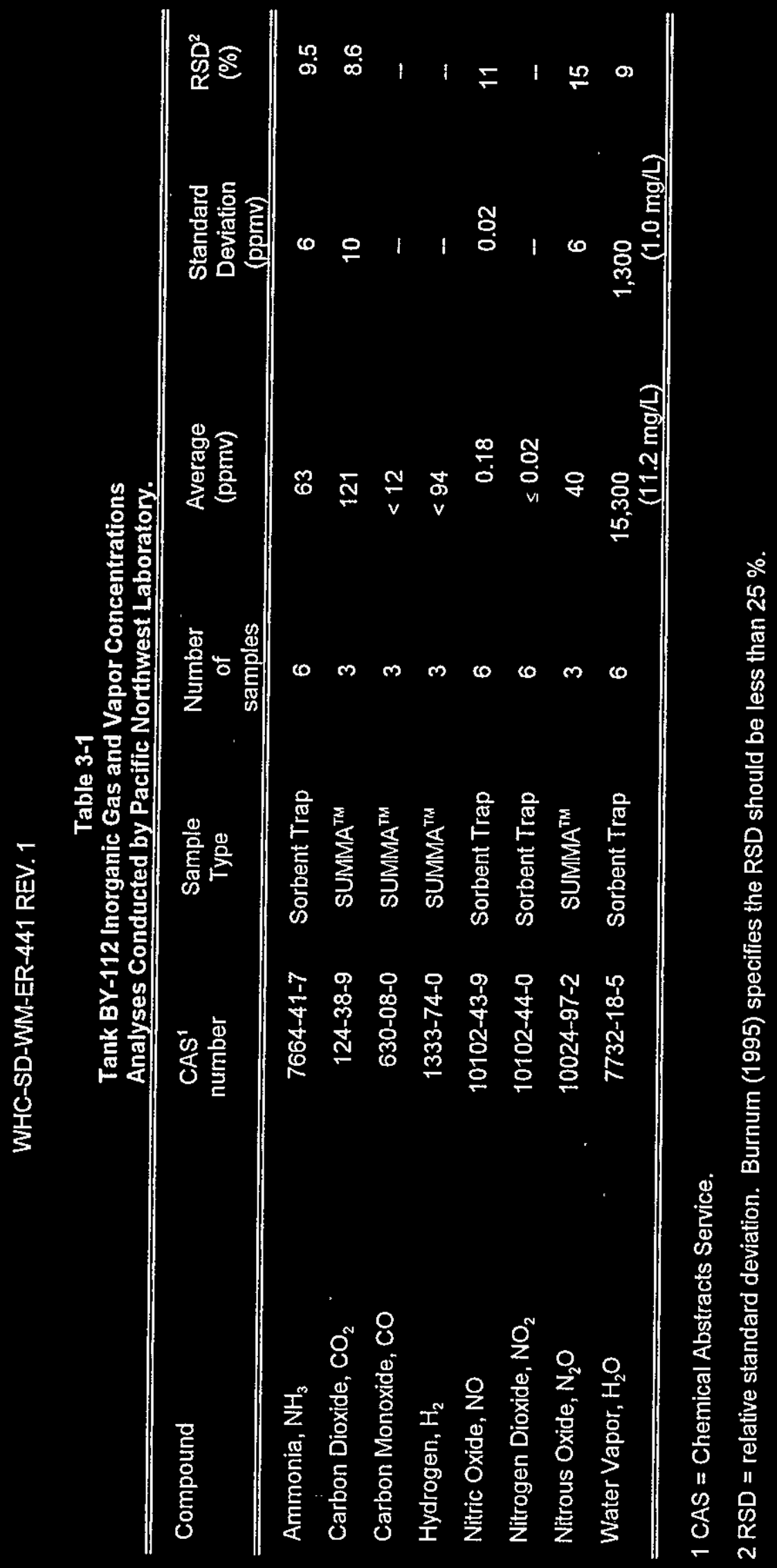


Table 3.2

Comparison of Tank BY-110, BY-111, and BY-112 Headspace Constituents ${ }^{1}$

\begin{tabular}{|c|c|c|c|}
\hline Tank: & BY $-110^{2}$ & $B Y-111^{3}$ & $B Y-112$ \\
\hline Date sampled, (mo/day/yr) & $11 / 11 / 94$ & $\begin{array}{c}5 / 11 / 94 \\
11 / 16 / 94\end{array}$ & $11 / 18 / 94$ \\
\hline Headspace temperature, $\left({ }^{\circ} \mathrm{C}\right)$ & 27 & 27 & 23.2 \\
\hline Ammonia, (ppmv) & 401 & 59 & 63 \\
\hline Hydrogen, (ppmv) & $<160$ & $<160$ & $<94$ \\
\hline Carbon dioxide, (ppmv) & 229 & 219 & 121 \\
\hline Carbon monoxide, (ppmv) & $<76$ & $<76$ & $<12$ \\
\hline Nitric oxide, (ppmv) & $=0.09$ & $\therefore 0.15$ & 0.18 \\
\hline Nitrogen dioxide, (ppmv) & $=0.05$ & $\leq 0.05$ & $\leq 0.02$ \\
\hline Nitrous oxide, (ppmv) & 103 & $<67$ & 40 \\
\hline Water vapor, $\left(\mathrm{mg} / \mathrm{m}^{3}\right)$ & 8.0 & 6.9 & 11.2 \\
\hline Water vapor, (\% relative humidity) & 31 & 27 & 53 \\
\hline Ethanenitrile (acetonitrile), (ppmv) & 0.81 & 0.050 & 0.10 \\
\hline Propanone (acetone), (ppmv) & (3.8) & $(0.48)$ & $(1.0)$ \\
\hline 1-Butanol, (ppmv) & 0.30 & $<0.0011$ & 0.059 \\
\hline n-Dodecane, (ppmv) & 0.079 & $<0.00046$ & 0.0097 \\
\hline n-Tridecane, (ppmv) & 0.13 & $(0.0015)$ & 0.020 \\
\hline Total organic compounds ${ }^{4},\left(\mathrm{mg} / \mathrm{m}^{3}\right)$ & 29 & 2.2 & 5.8 \\
\hline
\end{tabular}

1 Inorganic gas or vapor results are from PNL; organic vapor results are from ORNL, with non-quantitative values in parentheses and quantitative values not in parentheses.

2 Data are from Huckaby and Bratzel 1995a.

3 Data are from Huckaby and Bratzel 1995b.

4 Total organic compound concentration was estimated from TST sample resulis. 
WHC-SD-WM-ER-441 REV. 1

Table 4-1

Tank BY-112 Quantitatively Measured Organic Compounds in SUMMA ${ }^{\mathrm{TM}}$ Samples -Analyses by Pacific Northwest Laboratory

\begin{tabular}{llrrrr}
\hline $\begin{array}{c}\text { Cmpd } \\
\#\end{array}$ & Compound & $\begin{array}{c}\mathrm{CAS}^{1} \\
\text { Number }\end{array}$ & $\begin{array}{c}\text { Average } \\
(\mathrm{ppmv})\end{array}$ & $\begin{array}{c}\text { Standard } \\
\text { Deviation } \\
\text { (ppmv) }\end{array}$ & $\begin{array}{c}\mathrm{RSD}^{2} \\
(\%)\end{array}$ \\
\hline 1 & Trichlorofluoromethane & $75-69-4$ & 0.21 & 0.02 & 10 \\
2 & Toluene & $108-88-3$ & 0.041 & 0.0004 & 1 \\
3 & 2-Butanone & $78-93-3$ & 0.12 & 0.01 & 8 \\
4 & Propanone (acetone) & $67-64-1$ & 4.11 & 0.59 & 14 \\
5. & Methane & $74-82-8$ & $<61$ & - & - \\
\hline \hline
\end{tabular}

$1 \mathrm{CAS}=$ Chemical Abstract Service.

$2 \mathrm{RSD}=$ relative standard deviation. Burnum (1995) specifies the RSD should be less than $25 \%$. 
WHC-SD-WM-ER-441 REV. 1

Table 4-2

Tank BY-112 Quantitatively Measured Organic Compounds in TST Samples Analyses by Oak Ridge National Laboratory ${ }^{1}$

\begin{tabular}{clcccc}
\hline \hline $\begin{array}{c}\text { Cmpd } \\
\#\end{array}$ & Compound & $\begin{array}{c}\text { CAS }^{2} \\
\text { Number }\end{array}$ & $\begin{array}{c}\text { Average }^{3} \\
\text { (ppmv) }\end{array}$ & $\begin{array}{c}\text { Standard } \\
\text { Deviation } \\
\text { (ppmv) }\end{array}$ & $\begin{array}{c}\mathrm{RSD}^{4} \\
(\%)\end{array}$ \\
\hline 1 & Ethanenitrile (acetonitrile) & $75-05-8$ & 0.10 & 0.08 & 76 \\
2 & n-Dodecane & $112-40-3$ & 0.0097 & 0.0008 & 8 \\
3 & n-Tridecane & $629-50-5$ & 0.020 & 0.006 & 29 \\
\hline \hline
\end{tabular}

1 Results in this table are quantitative (as defined in Section 4.1).

$2 \mathrm{CAS}=$ Chemical Abstract Service.

3 Average of 3, 1-L TST samples.

$4 \mathrm{RSD}=$ relative standard deviation. Burnum (1995) specifies the RSD should be less than $25 \%$. 
Table 4-3

Tank BY-112 Positively Identified Organic Compounds in TST Samples Analyses by Oak Ridge National Laboratory ${ }^{1}$

\begin{tabular}{clrcrc}
\hline $\begin{array}{c}\text { Cmpd } \\
\#\end{array}$ & Compound & $\begin{array}{c}\text { CAS }^{2} \\
\text { Number }\end{array}$ & $\begin{array}{c}\text { Average } \\
(\text { ppmv })\end{array}$ & $\begin{array}{c}\text { Standard } \\
\text { Deviation } \\
\text { (ppmv) }\end{array}$ & $\begin{array}{c}\text { RSD }^{4} \\
(\%)\end{array}$ \\
\hline 1 & $\begin{array}{l}\text { Dichloromethane (methylene } \\
\text { chloride) }\end{array}$ & $75-09-2$ & 0.0016 & 0.0003 & 19 \\
2 & Propanenitrile & $107-12-0$ & 0.0024 & 0.0005 & 19 \\
3 & n-Hexane & $110-54-3$ & 0.0057 & 0.0004 & 7 \\
4 & Benzene & $71-43-2$ & 0.0020 & 0.0005 & 23 \\
5 & n-Butanenitrile & $109-74-0$ & 0.0049 & 0.0005 & 10 \\
6 & n-Heptane & $142-82-5$ & 0.0062 & 0.0040 & 64 \\
7 & Toluene & $108-88-3$ & 0.015 & 0.001 & 9 \\
8 & 2-Hexanone & $591-78-6$ & 0.0054 & 0.0009 & 17 \\
9 & n-Octane & $111-65-9$ & 0.0026 & 0.0009 & 35 \\
10 & n-Hexanenitrile & $628-73-9$ & 0.00093 & 0.00004 & 5 \\
11 & 2-Heptanone & $110-43-0$ & 0.0040 & 0.0003 & 7 \\
12 & n-Nonane & $111-84-2$ & 0.0019 & 0.0004 & 23 \\
13 & n-Heptanenitrile & $629-08-3$ & 0.00077 & 0.00006 & 7 \\
14 & 2-Octanone & $111-13-7$ & 0.0015 & 0.0001 & 4 \\
15 & n-Decane & $124-18-5$ & 0.0017 & 0.0001 & 5 \\
16 & n-Undecane & $1120-21-4$ & 0.0062 & 0.0005 & 8 \\
\hline \hline
\end{tabular}

1 Results in this table are not quantitative (as defined in Section 4.1) because measured values in at least 1 of the samples are outside instrument calibration limits.

$2 \mathrm{CAS}=$ Chemical Abstract Service.

3 Average of 3, 1-L TST samples.

4 RSD = relative standard deviation. Burnum (1995) specifies the RSD should be less than $25 \%$. 
WHC-SD-WM-ER-441 REV. 1

Table 4-4

Tank BY-112 Positively Identified Organic Compounds in TST Samples for which Practical Holding Times were Exceeded -Analyses by Oak Ridge National Laboratory"

\begin{tabular}{clrrrr}
\hline $\begin{array}{c}\text { Cmpd } \\
\#\end{array}$ & Compound & $\begin{array}{c}\text { CAS }^{2} \\
\text { Number }\end{array}$ & $\begin{array}{c}\text { Average } \\
\text { (ppmv) }\end{array}$ & $\begin{array}{c}\text { Standard } \\
\text { Deviation } \\
\text { (ppmv) }\end{array}$ & $\begin{array}{c}\text { RSD }^{4} \\
(\%)\end{array}$ \\
\hline 1 & Propanone $^{5}$ (acetone) & $67-64-1$ & 1.00 & 0.12 & 12 \\
2 & Butanal $^{6}$ & $123-72-8$ & 0.016 & 0.013 & 87 \\
3 & 1-Butanol & $71-36-3$ & 0.059 & 0.001 & 2 \\
4 & 2-Pentanone & $107-87-9$ & 0.020 & 0.004 & 17 \\
5 & n-Pentanenitrile & $110-59-8$ & 0.0012 & 0.00002 & 2 \\
\hline \hline
\end{tabular}

1 Practical holding times are defined and discussed in Section 4.1.

2 CAS $=$ Chemical Abstract Service.

3 Average of 3, 1-L TST samples.

4 RSD = relative standard deviation. Burnum (1995) specifies the RSD should be less than $25 \%$.

5 The concentration of this analyte was not quantitatively measured (as defined in Section 4.1), because the measured concentration was outside of the instrumental calibration limits.

6 The concentration of this analyte is quantitatively measured (as defined in Section 4.1). 
Table 4-5

Tank BY-112 Comparison of Organic Compounds in TST and SUMMA ${ }^{\text {TM }}$ Samples-Analyses by Oak Ridge National Laboratory and Pacific Northwest Laboratory

\begin{tabular}{lcccc}
\hline Compound & $\begin{array}{c}\text { CAS }^{1} \\
\text { Number }\end{array}$ & $\begin{array}{c}\text { TST } \\
\text { Average } \\
\text { (ppmv) }\end{array}$ & $\begin{array}{c}\text { SUMMA } \\
\text { Average }^{\text {TM }} \\
\text { (ppmV) }\end{array}$ & $\begin{array}{c}\text { PRD }^{4} \\
(\%)\end{array}$ \\
\hline \hline $\begin{array}{l}\text { 1,1-Dichloroethene (vinylidene chloride) } \\
\text { Dichloromethane (methylene chloride) }\end{array}$ & $75-35-4$ & $<0.0023$ & $<0.005$ & - \\
Propanone (acetone) & $75-09-2$ & $<0.0053$ & $<0.005$ & - \\
Ethanenitrile (acetonitrile) & $67-64-1$ & 1.0 & 4.1 & 122 \\
Propanenitrile & $75-05-8$ & 0.10 & $<0.005$ & $>181$ \\
n-Butanenitrile & $107-12-0$ & 0.0024 & $<0.005$ & - \\
Benzene & $109-74-0$ & 0.0049 & $<0.005$ & - \\
Toluene & $71-43-2$ & 0.0020 & $<0.005$ & - \\
n-Hexane & $108-88-3$ & 0.015 & 0.041 & 93 \\
n-Heptane & $110-54-3$ & 0.0057 & $<0.005$ & $>13$ \\
n-Decane & $142-82-5$ & 0.0062 & $<0.005$ & $>21$ \\
\hline \hline
\end{tabular}

$1 \mathrm{CAS}=$ Chemical Abstract Service.

2 Average of 3, 1-L TST samples from ORNL.

3 Average of 3 samples from PNL.

$4 \mathrm{PRD}=$ percent relative difference. Keller (1994) requires the PRD to be less than $20 \%$. 
Table 4-6

Tank BY-112 Tentatively ldentified Organic Compounds in SUMMA ${ }^{T M}$ Samples -Analyses by Pacific Northwest Laboratory

\begin{tabular}{clccc}
\hline $\begin{array}{c}\text { Cmpd } \\
\#\end{array}$ & Compound & $\begin{array}{c}\text { CAS }^{1} \\
\text { Number }\end{array}$ & $\begin{array}{c}\text { Average }^{2} \\
\left(\mathrm{mg} / \mathrm{m}^{3}\right)\end{array}$ & $\begin{array}{c}\text { Standard } \\
\text { Deviation } \\
\left(\mathrm{mg} / \mathrm{m}^{3}\right)\end{array}$ \\
\hline \hline 1 & Propene $^{4}$ & $115-07-1$ & 0.05 & 0.01 \\
2 & Propane & $74-98-6$ & 0.063 & 0.015 \\
3 & Cyclopropane & $75-19-4$ & 0.12 & 0.01 \\
4 & Ethanal (acetaldehyde) & $75-07-0$ & 0.16 & 0.02 \\
5 & Butane & $106-97-8$ & 0.12 & 0.03 \\
6 & Ethanol & $64-17-5$ & 0.10 & 0.01 \\
7 & n-Pentane & $109-66-0$ & 0.073 & 0.04 \\
8 & 2-Methyl-2-propanol & $75-65-0$ & 0.24 & 0.02 \\
9 & Butanal & $123-72-8$ & 0.076 & 0.006 \\
10 & 3-Methyl-2-butanone & $563-80-4$ & $<0.04$ & - \\
11 & 1-Butanol & $71-36-3$ & 0.087 & 0.006 \\
12 & 2-Pentanone & $107-87-9$ & 0.077 & 0.006 \\
13 & 4,4-Dimethyl-2-pentanone & $590-50-1$ & 0.13 & 0.02 \\
\hline \hline Sum of tentatively identified compounds: & & 1.31 & \\
\hline \hline
\end{tabular}

$1 \mathrm{CAS}=$ Chemical Abstract Service.

2 Average of 3 samples, values listed are estimates.

3 When the analyte was detected in only 2 samples, the entry is the relative difference (i.e., their difference divided by 2).

4 Detected in only two samples. 
Table 4-7

Tank BY-112 Tentatively Identified Organic Compounds in TST Samples In the Order of Chromatographic Elution -Analyses by Oak Ridge National Laboratory

\begin{tabular}{|c|c|c|c|c|}
\hline$\underset{\#}{\text { Cmpd }}$ & Compound & $\begin{array}{l}\text { CAS }^{1} \\
\text { Number }\end{array}$ & $\begin{array}{c}\text { Average }^{2} \\
\left(\mathrm{mg} / \mathrm{m}^{3}\right)\end{array}$ & $\begin{array}{l}\text { Standard } \\
\text { Deviation } \\
\left(\mathrm{mg} / \mathrm{m}^{3}\right)\end{array}$ \\
\hline 1 & Methyl nitrite & $624-91-9$ & 0.0049 & 0.0084 \\
\hline 2 & Cyclopropane & $75-19-4$ & 0.011 & 0.010 \\
\hline 3 & 1.Propene, 2-methyl- & $115-11-7$ & 0.046 & 0.041 \\
\hline 4 & Methanol & $67-56-1$ & 0.36 & 0.45 \\
\hline 5 & Ethanot & $64-17-5$ & 0.083 & 0.018 \\
\hline 6 & Trichlorofluoromethane & $75-69-4$ & 0.43 & 0.06 \\
\hline 7 & Trichlorofluoromethane & $75-69-4$ & 0.076 & 0.131 \\
\hline 8 & 2- Propanol & $67-63-0$ & 0.13 & 0.12 \\
\hline 9 & 2-Propanol, 2-methyl- & $75-65-0$ & 0.0044 & 0.0076 \\
\hline 10 & 1.-Propanol & $71-23-8$ & 0.063 & 0.012 \\
\hline 11 & Acetic acid & $64-19-7$ & 0.072 & 0.125 \\
\hline 12 & 2-Butanone & $78-93-3$ & 0.075 & 0.066 \\
\hline 13 & 2-Butanone, 3-methyl- & $563-80-4$ & 0.016 & 0.002 \\
\hline 14 & Nitric acid, propyl ester & $627-13-4$ & 0.0047 & 0.0081 \\
\hline 15 & 2-Pentene, 4-methyl-and others & & 0.0058 & 0.0101 \\
\hline 16 & 3-Pentanone & $96-22-0$ & 0.0083 & 0.0072 \\
\hline 17 & 2-Butanone, 3,3-dimethyl- & $75-97-8$ & 0.031 & 0.023 \\
\hline 18 & 2-Butanone, 3,3-dimethyl- & $75-97-8$ & 0.013 & 0.011 \\
\hline 19 & Formamide & $75-12-7$ & 0.0028 & 0.0049 \\
\hline 20 & 1-Butanol, 3-methyl- & $123-51-3$ & 0.0060 & 0.0052 \\
\hline 21 & 1-Butanol, 3-methyl-, nitrate & $543-87-3$ & 0.0028 & 0.0049 \\
\hline 22 & 2-Pentanone, 4,4-dimethyl- & $590-50-1$ & 0.055 & 0.006 \\
\hline 23 & Cyciotrisiloxane, hexamethyl- & $541-05-9$ & 0.0088 & 0.0081 \\
\hline 24 & 2,2,4-Trimethyl-3-pentanone & $5857-36-3$ & 0.011 & 0.00008 \\
\hline 25 & Ethylbenzene & $100-41-4$ & 0.0099 & 0.0004 \\
\hline 26 & 1-Hexanol & $111-27-3$ & 0.0052 & 0.0045 \\
\hline 27 & Benzene, 1,3-dimethyl- & $108-38-3$ & 0.023 & 0.0007 \\
\hline
\end{tabular}


WHC-SD-WM-ER-441 REV. 1

\begin{tabular}{|c|c|c|c|c|}
\hline Cmpd & Compound & $\begin{array}{l}\mathrm{CAS}^{1} \\
\text { Number }\end{array}$ & $\begin{array}{l}\text { Average }^{2} \\
\left(\mathrm{mg} / \mathrm{m}^{3}\right)\end{array}$ & $\begin{array}{c}\text { Standard } \\
\text { Deviation } \\
\left(\mathrm{mg} / \mathrm{m}^{3}\right)\end{array}$ \\
\hline 28 & 3-Heptanone & $106-35-4$ & 0.023 & 0.002 \\
\hline 29 & p-Xylene & $106-42-3$ & 0.0024 & 0.0041 \\
\hline 30 & 3-Heptanone, 6-methyl- & $624-42-0$ & 0.011 & 0.0002 \\
\hline 31 & 2-Heptanone, 6-methyl- & $928-68-7$ & 0.031 & 0.002 \\
\hline 32 & Benzaldehyde & $100-52-7$ & 0.015 & 0.002 \\
\hline 33 & 1-Hexanol, 2-ethyl- & 104-76-7 & 0.0019 & 0.0034 \\
\hline 34 & 2(3H)-Furanone, dihydro-4,4-dimethyl- & $13861-97-7$ & 0.0020 & 0.0035 \\
\hline 35 & C10-Alkane & & 0.020 & 0.002 \\
\hline 36 & 2-Heptanone, 4,6-dimethyl- & $19549-80-5$ & 0.0020 & 0.0035 \\
\hline 37 & 1-Octanol & $111-87-5$ & 0.0022 & 0.0038 \\
\hline 38 & Acetophenone & $98-86-2$ & 0.0029 & 0.0051 \\
\hline 39 & Nonanal & $124-19-6$ & 0.0021 & 0.0037 \\
\hline 40 & Undecane, 2,6-dimethyl- & $17301-23-4$ & 0.0094 & 0.0023 \\
\hline 41 & Cyclohexane, hexyl- & $4292-75-5$ & 0.0039 & 0.0067 \\
\hline 42 & Tridecane, 7-methyl- & $26730-14-3$ & 0.026 & 0.006 \\
\hline 43 & Methenamine & $100-97-0$ & 0.0026 & 0.0046 \\
\hline 44 & Undecane, 5-ethyl- & $17453-94-0$ & 0.012 & 0.003 \\
\hline 45 & Cyclohexane, pentyl- & $4292-92-6$ & 0.014 & 0.004 \\
\hline 46 & Tridecane, 2-methyl- & $1560-96-9$ & 0.0097 & 0.0019 \\
\hline 47 & Tridecane, 3-methyl- & $6418-41-3$ & 0.0087 & 0.0017 \\
\hline 48 & Dodecane, 2,6,10-trimethyl- & $3891-98-3$ & 0.073 & 0.013 \\
\hline 49 & n-Tetradecane & $629-59-4$ & 0.10 & 0.02 \\
\hline 50 & Tridecane, 4,8-dimethyl- & $55030-62-1$ & 0.011 & 0.001 \\
\hline 51 & $\begin{array}{l}\text { Cyclohexane,1,1,3-trimethyl-2- } \\
\text { (3-methyl-pentyl) }\end{array}$ & $54965-05-8$ & 0.0097 & 0.0009 \\
\hline 52 & Dodecane, 2,6,10-trimethyl- & $3891-98-3$ & 0.0018 & 0.0031 \\
\hline 53 & n-Hexadecane & $544-76-3$ & 0.057 & 0.006 \\
\hline 54 & $\mathrm{n}$-Heptadecane & $629-78-7$ & 0.045 & 0.007 \\
\hline 55 & Cyclohexane, 1,2-dimethyl-3-pentyl- & & 0.0062 & 0.0055 \\
\hline
\end{tabular}


WHC-SD-WM-ER-441 REV. 1

\begin{tabular}{clrrr}
\hline $\begin{array}{c}\text { Cmpd } \\
\#\end{array}$ & Compound & $\begin{array}{c}\text { CAS }^{1} \\
\text { Number }\end{array}$ & $\begin{array}{c}\text { Average } \\
\left(\mathrm{mg} / \mathrm{m}^{3}\right)\end{array}$ & $\begin{array}{c}\text { Standard } \\
\text { Deviation } \\
\left(\mathrm{mg} / \mathrm{m}^{3}\right)\end{array}$ \\
\hline 56 & 3-Ethyl-2-methyl-2-heptanol & & 0.0046 & 0.0040 \\
57 & 6-Dodecanol & $6836-38-0$ & 0.0047 & 0.0041 \\
58 & n-Hexadecane & $544-76-3$ & 0.0096 & 0.0025 \\
59 & Butyric acid, thio-, S-decyl ester & $2432-55-5$ & 0.013 & 0.002 \\
60 & Diethyl phthalate & $84-66-2$ & 0.029 & 0.012 \\
61 & 1,1'-Biphenyl, 2,2'-dichloro- & $13029-08-8$ & 0.0021 & 0.004 \\
62 & Benzenesulfonamide, N-butyl- & $3622-84-2$ & 0.052 & 0.023 \\
63 & Benzenesulfonamide, N-ethyl-4-methyl- & $80-39-7$ & 0.0042 & 0.0073 \\
64 & Benzenesulfonamide, N-butyl- & $3622-84-2$ & 0.015 & 0.026 \\
65 & Dibutyl phthalate & & 0.0020 & 0.0035 \\
66 & Isopropyl palmitate & $142-91-6$ & 0.012 & 0.002 \\
\hline \hline Sum of tentatively identified compounds: & & 2.22 & \\
\hline \hline
\end{tabular}

$1 \mathrm{CAS}=$ Chemical Abstract Service.

2 Average of 3, 1-L TST samples, values listed are estimates. 
WHC-SD-WM-ER-441 REV. 1

Table 4-8

Tank BY-112 Tentatively Identified Organic Compounds in TST Samples Sorted Alphanumerically Analyses by Oak Ridge National Laboratory

\begin{tabular}{|c|c|c|c|c|}
\hline Cmpd & Compound & $\begin{array}{c}\mathrm{CAS}^{1} \\
\text { Number }\end{array}$ & $\begin{array}{l}\text { Average }^{2} \\
\left(\mathrm{mg} / \mathrm{m}^{3}\right)\end{array}$ & $\begin{array}{c}\text { Standard } \\
\text { Deviation } \\
\left(\mathrm{mg} / \mathrm{m}^{3}\right)\end{array}$ \\
\hline 10 & 1-Propanol & $71-23-8$ & 0.063 & 0.012 \\
\hline 37 & 1-Octanol & $111-87-5$ & 0.0022 & 0.0038 \\
\hline 3 & 1-Propene, 2-methyl- & $115-11-7$ & 0.046 & 0.041 \\
\hline 21 & 1-Butanol, 3-methyl-, nitrate & $543-87-3$ & 0.0028 & 0.0049 \\
\hline 26 & 1-Hexanol & $111-27-3$ & 0.0052 & 0.0045 \\
\hline 20 & 1-Butanol, 3-methyl- & $123-51-3$ & 0.0060 & 0.0052 \\
\hline 33 & 1-Hexanol, 2-ethyl- & $104-76-7$ & 0.0019 & 0.0034 \\
\hline 61 & 1,1'-Biphenyl, 2,2'-dichloro- & $13029-08-8$ & 0.0021 & 0.004 \\
\hline 9 & 2-Propanol, 2-methyl- & $75-65-0$ & 0.0044 & 0.0076 \\
\hline 36 & 2-Heptanone, 4,6-dimethyl- & $19549-80-5$ & 0.0020 & 0.0035 \\
\hline 18 & 2-Butanone, 3,3-dimethyl- & $75-97-8$ & 0.013 & 0.011 \\
\hline 12 & 2-Butanone & $78-93-3$ & 0.075 & 0.066 \\
\hline 13 & 2-Butanone, 3-methyl- & $563-80-4$ & 0.016 & 0.002 \\
\hline 31 & 2-Heptanone, 6-methyl- & $928-68-7$ & 0.031 & 0.002 \\
\hline 15 & 2-Pentene, 4-methyl- and others & & 0.0058 & 0.0101 \\
\hline 22 & 2-Pentanone, 4,4-dimethyl- & $590-50-1$ & 0.055 & 0.006 \\
\hline 17 & 2-Butanone, 3,3-dimethyl- & $75-97-8$ & 0.031 & 0.023 \\
\hline 24 & 2,2,4-Trimethyl-3-pentanone & $5857-36-3$ & 0.011 & 0.00008 \\
\hline 34 & 2(3H)-Furanone, dihydro-4,4-dimethyl- & $13861-97-7$ & 0.0020 & 0.0035 \\
\hline 8 & 2-Propanol & $67-63-0$ & 0.13 & 0.12 \\
\hline 56 & 3-Ethyl-2-methyl-2-heptanol & & 0.0046 & 0.0040 \\
\hline 16 & 3-Pentanone & $96-22-0$ & 0.0083 & 0.0072 \\
\hline 28 & 3-Heptanone & $106-35-4$ & 0.023 & 0.002 \\
\hline .30 & 3-Heptanone, 6-methyl- & $624-42-0$ & 0.011 & 0.0002 \\
\hline 57 & 6-Dodecanol & $6836-38-0$ & 0.0047 & 0.0041 \\
\hline 11 & Acetic acid & $64-19-7$ & 0.072 & 0.125 \\
\hline 38 & Acetophenone & $98-86-2$ & 0.0029 & 0.0051 \\
\hline
\end{tabular}


WHC-SD-WM-ER-441 REV. 1

\begin{tabular}{|c|c|c|c|c|}
\hline$\underset{\#}{\text { Cmpd }}$ & Compound & $\begin{array}{c}\mathrm{CAS}^{1} \\
\text { Number }\end{array}$ & $\begin{array}{c}\text { Average }^{2} \\
\left(\mathrm{mg} / \mathrm{m}^{3}\right)\end{array}$ & $\begin{array}{l}\text { Standard } \\
\text { Deviation } \\
\left.\text { (mg/m } \mathrm{m}^{3}\right)\end{array}$ \\
\hline 32 & Benzaldehyde & $100-52-7$ & 0.015 & 0.002 \\
\hline 27 & Benzene, 1,3-dimethyl- & $108-38-3$ & 0.023 & 0.0007 \\
\hline 62 & Benzenesulfonamide, $\mathrm{N}$-butyl- & $3622-84-2$ & 0.052 & 0.023 \\
\hline 63 & Benzenesulfonamide, $\mathrm{N}$-ethyl-4-methyl- & $80-39-7$ & 0.0042 & 0.0073 \\
\hline 64 & Benzenesulfonamide, N-butyl- & $3622-84-2$ & 0.015 & 0.026 \\
\hline 59 & Butyric acid, thio-, S-decyl ester & $2432-55-5$ & 0.013 & 0.002 \\
\hline 35 & C10-Alkane & & 0.020 & 0.002 \\
\hline 41 & Cyclohexane, hexyl- & $4292-75-5$ & 0.0039 & 0.0067 \\
\hline 45 & Cyclohexane, pentyl- & $4292-92-6$ & 0.014 & 0.004 \\
\hline 55 & Cyciohexane, 1,2-dimethyl-3-pentyl- & & 0.0062 & 0.0055 \\
\hline 51 & $\begin{array}{l}\text { Cyclohexane, 1,1,3-trimethyl- } \\
\text { 2-(3-methylpentyl) }\end{array}$ & $54965-05-8$ & 0.0097 & 0.0009 \\
\hline 2 & Cyclopropane & $75-19-4$ & 0.011 & 0.010 \\
\hline 23 & Cyclotrisiloxane, hexamethyl- & $541-05-9$ & 0.0088 & 0.0081 \\
\hline 65 & Dibutyl phthalate & & 0.0020 & 0.0035 \\
\hline 60 & Diethyl phthalate & $84-66-2$ & 0.029 & $0.012^{\circ}$ \\
\hline 48 & Dodecane, 2,6,10-trimethyl- & $3891-98-3$ & 0.073 & 0.013 \\
\hline 52 & Dodecane, $2,6,10$-trimethyl- & $3891-98-3$ & 0.0018 & 0.0031 \\
\hline 5 & Ethanol & $64-17-5$ & 0.083 & 0.018 \\
\hline 25 & Ethylbenzene & $100-41-4$ & 0.0099 & 0.0004 \\
\hline 19 & Formamide & $75-12-7$ & 0.0028 & 0.0049 \\
\hline 66 & Isopropyl paimitate & $142-91-6$ & 0.012 & 0.002 \\
\hline 4 & Methanol & $67-56-1$ & 0.36 & 0.45 \\
\hline 43 & Methenamine & $100-97-0$ & 0.0026 & 0.0046 \\
\hline 1 & Methyl nitrite & $624-91-9$ & 0.0049 & 0.0084 \\
\hline 54 & n-Heptadecane & $629-78-7$ & 0.045 & 0.007 \\
\hline 53 & n-Hexadecane & $544-76-3$ & 0.057 & 0.006 \\
\hline 58 & n-Hexadecane & $544-76-3$ & 0.0096 & 0.0025 \\
\hline 49 & - $n$-Tetradecane & $629-59-4$ & 0.10 & 0.02 \\
\hline
\end{tabular}


WHC-SD-WM-ER-441 REV. 1

\begin{tabular}{clrrr}
\hline $\begin{array}{c}\text { Cmpd } \\
\#\end{array}$ & Compound & $\begin{array}{c}\text { CAS }^{1} \\
\text { Number }\end{array}$ & $\begin{array}{c}\text { Average } \\
\left(\mathrm{mg} / \mathrm{m}^{3}\right)\end{array}$ & $\begin{array}{c}\text { Standard } \\
\text { Deviation } \\
\left(\mathrm{mg} / \mathrm{m}^{3}\right)\end{array}$ \\
\hline 14 & Nitric acid, propyl ester & $627-13-4$ & 0.0047 & 0.0081 \\
39 & Nonanal & $124-19-6$ & 0.0021 & 0.0037 \\
29 & p-Xylene & $106-42-3$ & 0.0024 & 0.0041 \\
6 & Trichlorofluoromethane & $75-69-4$ & 0.43 & 0.06 \\
7 & Trichlorofluoromethane & $75-69-4$ & 0.076 & 0.131 \\
42 & Tridecane, 7-methyl- & $26730-14-3$ & 0.026 & 0.006 \\
46 & Tridecane, 2-methyl- & $1560-96-9$ & 0.0097 & 0.0019 \\
47 & Tridecane, 3-methyl- & $6418-41-3$ & 0.0087 & 0.0017 \\
50 & Tridecane, 4,8-dimethyl- & $55030-62-1$ & 0.011 & 0.001 \\
40 & Undecane, 2,6-dimethyl- & $17301-23-4$ & 0.0094 & 0.0023 \\
44 & Undecane, 5-ethyl- & $17453-94-0$ & 0.012 & 0.003 \\
\hline \hline Sum of tentatively identified compounds: & & 2.22 & \\
\hline \hline
\end{tabular}

$1 \mathrm{CAS}=$ Chemical Abstract Service .

2 Average of 3,1-L. TST samples, values listed are estimates. 
Table 4-9

Tank BY-112 Tentatively Identified Organic Compounds in TST Samples Sorted by Estimated Concentration Analyses by Oak Ridge National Laboratory

\begin{tabular}{|c|c|c|c|c|}
\hline$\underset{\#}{\text { Cmpd }}$ & Compound & $\begin{array}{c}\text { CAS }^{1} \\
\text { Number }\end{array}$ & $\begin{array}{l}\text { Average }^{2} \\
\left(\mathrm{mg} / \mathrm{m}^{3}\right)\end{array}$ & $\begin{array}{l}\text { Standard } \\
\text { Deviation } \\
\left(\mathrm{mg} / \mathrm{m}^{3}\right)\end{array}$ \\
\hline 6 & Trichlorofluoromethane & $75-69-4$ & 0.43 & 0.06 \\
\hline 4 & Methanol & $67-56-1$ & 0.36 & 0.45 \\
\hline 8 & 2- Propanol & $67-63-0$ & 0.13 & 0.12 \\
\hline 49 & n-Tetradecane & $629-59-4$ & 0.10 & 0.02 \\
\hline 5 & Ethanol & $64-17-5$ & 0.083 & 0.018 \\
\hline 7 & Trichlorofluoromethane & $75-69-4$ & 0.076 & 0.131 \\
\hline 12 & 2-Butanone & $78-93-3$ & 0.075 & 0.066 \\
\hline 48 & Dodecane, 2,6,10-trimethyl- & $3891-98-3$ & 0.073 & 0.013 \\
\hline 11 & Acetic acid & $64-19-7$ & 0.072 & 0.125 \\
\hline 10 & 1-Propanol & $71-23-8$ & 0.063 & 0.012 \\
\hline 53 & n-Hexadecane & $544-76-3$ & 0.057 & 0.006 \\
\hline 22 & 2-Pentanone, 4,4-dimethyl- & $590-50-1$ & 0.055 & 0.006 \\
\hline 62 & Benzenesulfonamide, N-butyl- & $3622-84-2$ & 0.052 & 0.023 \\
\hline 3 & 1-Propene, 2-methyl- & $115-11-7$ & 0.046 & 0.041 \\
\hline 54 & n-Heptadecane & $629-78-7$ & 0.045 & 0.007 \\
\hline 31 & 2-Heptanone, 6-methyl- & $928-68-7$ & 0.031 & 0.002 \\
\hline 17 & 2-Butanone, 3,3-dimethyl- & $75-97-8$ & 0.031 & 0.023 \\
\hline 60 & Diethyl phthalate & $84-66-2$ & 0.029 & 0.012 \\
\hline 42 & Tridecane, 7-methyl- & $26730-14-3$ & 0.026 & 0.006 \\
\hline 27 & Benzene, 1,3-dimethyl- & $108-38-3$ & 0.023 & 0.0007 \\
\hline 28 & 3-Heptanone & $106-35-4$ & 0.023 & 0.002 \\
\hline 35 & C10-Alkane & & 0.020 & 0.002 \\
\hline 13 & 2-Butanone, 3-methyl- & $563-80-4$ & 0.016 & 0.002 \\
\hline 32 & Benzaldehyde & $100-52-7$ & 0.015 & 0.002 \\
\hline 64 & Benzenesulfonamide, N-butyl- & $3622-84-2$ & 0.015 & 0.026 \\
\hline 45 & Cyclohexane, pentyl- & $4292-92-6$ & 0.014 & 0.004 \\
\hline 59 & Butyric acid, thio-, S-decyl ester & $2432-55-5$ & 0.013 & 0.002 \\
\hline
\end{tabular}


WHC-SD-WM-ER-441 REV. 1

\begin{tabular}{|c|c|c|c|c|}
\hline Cmpd & Compound & $\begin{array}{c}\mathrm{CAS}^{1} \\
\text { Number }\end{array}$ & $\begin{array}{l}\text { Average }^{2} \\
\left(\mathrm{mg} / \mathrm{m}^{3}\right)\end{array}$ & $\begin{array}{c}\text { Standard } \\
\text { Deviation } \\
\left(\mathrm{mg} / \mathrm{m}^{3}\right)\end{array}$ \\
\hline 18 & 2-Butanone, 3,3-dimethyl- & $75-97-8$ & 0.013 & 0.011 \\
\hline 66 & Isopropyl palmitate & $142-91-6$ & 0.012 & 0.002 \\
\hline 44 & Undecane, 5-ethyl- & $17453-94-0$ & 0.012 & 0.003 \\
\hline 24 & 2,2,4-Trimethyl-3-pentanone & $5857-36-3$ & 0.011 & 0.00008 \\
\hline 50 & Tridecane, 4,8-dimethyl- & $55030-62-1$ & 0.011 & 0.001 \\
\hline 2 & Cyclopropane & $75-19-4$ & 0.011 & 0.010 \\
\hline 30 & 3-Heptanone, 6-methyl- & $624-42-0$ & 0.011 & 0.0002 \\
\hline 25 & Ethylbenzene & $100-41-4$ & 0.0099 & 0.0004 \\
\hline 46 & Tridecane, 2-methyl- & $1560-96-9$ & 0.0097 & 0.0019 \\
\hline 51 & $\begin{array}{l}\text { Cyclohexane,1,1,3-trimethyl- } \\
\text { 2-(3-methylpentyl) }\end{array}$ & $54965-05-8$ & 0.0097 & 0.0009 \\
\hline 58 & n-Hexadecane & $544-76-3$ & 0.0096 & 0.0025 \\
\hline 40 & Undecane, 2,6-dimethyl- & $17301-23-4$ & 0.0094 & 0.0023 \\
\hline 23 & Cyclotrisiloxane, hexamethyl- & $541-05-9$ & 0.0088 & 0.0081 \\
\hline 47 & Tridecane, 3-methyl- & $6418-41-3$ & 0.0087 & 0.0017 \\
\hline 16 & 3-Pentanone & $96-22-0$ & 0.0083 & 0.0072 \\
\hline 55 & Cyclohexane, 1,2-dimethyl-3-pentyl- & & 0.0062 & 0.0055 \\
\hline 20 & 1-Butanol, 3-methy- & $123-51-3$ & 0.0060 & 0.0052 \\
\hline 15 & 2-Pentene, 4-methyl- and others & & 0.0058 & 0.0101 \\
\hline 26 & 1-Hexanol & $111-27-3$ & 0.0052 & 0.0045 \\
\hline 1 & Methyl nitrite & $624-91-9$ & 0.0049 & 0.0084 \\
\hline 57 & 6-Dodecanol & & 0.0047 & 0.0041 \\
\hline 14 & Nitric acid, propyl ester & $627-13-4$ & 0.0047 & 0.0081 \\
\hline 56 & 3-Ethyl-2-methyl-2-heptanol & & 0.0046 & 0.0040 \\
\hline 9 & 2-Propanol, 2-methyl- & $75-65-0$ & 0.0044 & 0.0076 \\
\hline 63 & Benzenesulfonamide, N-ethyl-4-methyl- & $80-39-7$ & 0.0042 & 0.0073 \\
\hline 41 & Cyclohexane, hexyl- & $4292-75-5$ & 0.0039 & 0.0067 \\
\hline 38 & Acetophenone & $98-86-2$ & 0.0029 & 0.0051 \\
\hline 21 & 1-Butanol, 3-methyl-, nitrate & $543-87-3$ & 0.0028 & 0.0049 \\
\hline
\end{tabular}


WHC-SD-WM-ER-441 REV. 1

\begin{tabular}{clrrr}
$\begin{array}{c}\text { Cmpd } \\
\#\end{array}$ & Compound & $\begin{array}{c}\text { CAS' } \\
\text { Number }\end{array}$ & $\begin{array}{c}\text { Average }{ }^{2} \\
\left(\mathrm{mg}^{3} / \mathrm{m}^{3}\right)\end{array}$ & $\begin{array}{c}\text { Standard } \\
\text { Deviation } \\
\left(\mathrm{mg} / \mathrm{m}^{3}\right)\end{array}$ \\
\hline 19 & Formamide & $\begin{array}{r}75-12-7 \\
100-97-0\end{array}$ & 0.0028 & 0.0049 \\
43 & Methenamine & $106-42-3$ & 0.0026 & 0.0046 \\
29 & p-Xylene & $111-87-5$ & 0.0022 & 0.0041 \\
37 & 1-Octanol & $124-19-6$ & 0.0021 & 0.0037 \\
39 & Nonanal & $13029-08-8$ & 0.0021 & 0.004 \\
61 & 1,1'-Biphenyl, 2,2'-dichloro & $19549-80-5$ & 0.0020 & 0.0035 \\
36 & 2-Heptanone, 4,6-dimethyl- & $13861-97-7$ & 0.0020 & 0.0035 \\
34 & 2(3H)-Furanone, dihydro-4,4-dimethyl- & & 0.0020 & 0.0035 \\
65 & Dibutyl phthalate & $104-76-7$ & 0.0019 & 0.0034 \\
33 & 1-Hexanol, 2-ethyl- & $3891-98-3$ & 0.0018 & 0.0031 \\
52 & Dodecane, 2,6,10-trimethyl- & & 2.22 & \\
\hline \hline Sum of tentatively identified compounds: & &
\end{tabular}

$1 \mathrm{CAS}=$ Chemical Abstract Service.

2 Average of 3,1-L TST samples, values listed are estimates. 